IZA DP No. 4538

Happiness in Europe: Cross-Country Differences in the Determinants of Subjective Well-Being

Peder J. Pedersen

Torben Dall Schmidt

October 2009 


\title{
Happiness in Europe: Cross-Country Differences in the Determinants of Subjective Well-Being
}

\author{
Peder J. Pedersen \\ University of Aarhus, \\ SFI and IZA
}

\author{
Torben Dall Schmidt \\ University of Southern Denmark
}

Discussion Paper No. 4538

October 2009

\author{
IZA \\ P.O. Box 7240 \\ 53072 Bonn \\ Germany \\ Phone: +49-228-3894-0 \\ Fax: +49-228-3894-180 \\ E-mail: iza@iza.org
}

Any opinions expressed here are those of the author(s) and not those of IZA. Research published in this series may include views on policy, but the institute itself takes no institutional policy positions.

The Institute for the Study of Labor (IZA) in Bonn is a local and virtual international research center and a place of communication between science, politics and business. IZA is an independent nonprofit organization supported by Deutsche Post Foundation. The center is associated with the University of Bonn and offers a stimulating research environment through its international network, workshops and conferences, data service, project support, research visits and doctoral program. IZA engages in (i) original and internationally competitive research in all fields of labor economics, (ii) development of policy concepts, and (iii) dissemination of research results and concepts to the interested public.

IZA Discussion Papers often represent preliminary work and are circulated to encourage discussion. Citation of such a paper should account for its provisional character. A revised version may be available directly from the author. 
IZA Discussion Paper No. 4538

October 2009

\section{ABSTRACT}

\section{Happiness in Europe: Cross-Country Differences in the Determinants of Subjective Well-Being}

The purpose in the present paper is to use individual panel data in the European Community Household Panel to analyse the impact on self-reported satisfaction from a number of economic and demographic variables. The paper contributes to the ongoing discussion of the relationship between life satisfaction and income. The panel property of the data makes it possible to study also the impact on satisfaction from income changes as well as the impact from acceleration in income and changes in labour market status on changes in satisfaction. A number of demographic variables and individual attitude indicators are also entered into the analysis of both the level of satisfaction and the change in satisfaction from one wave of the survey to the next. We find a strong impact from the level of income in all countries, an impact from change and acceleration in income for a smaller number of countries, a strong impact from most changes in labour market status and finally important effects from a number of demographic variables.

JEL Classification: $\quad$ C23, D31, I31, J28

Keywords: $\quad$ satisfaction, income, labour market status, health

Corresponding author:

Peder J. Pedersen

Department of Economics

University of Aarhus

DK-8000 Aarhus C

Denmark

E-mail: ppedersen@econ.au.dk

\footnotetext{
*Earlier versions of the paper have been presented at the EPUNET Conference in Barcelona, at the Department of Economics at Växjö Umiversity and at the ISQOLS Conference in San Diego. We are grateful for useful comments and suggestions at these occasions.
} 


\section{Introduction}

Economic success or failure is conventionally measured by a number of standard indicators, i.e. the real GDP growth, level and trend in unemployment and measures of the income distribution, poverty and social exclusion. In the present study we look instead at the level of individual subjective well-being or satisfaction based on the response to a survey question in the European Community Household Panel (ECHP) regarding the level of satisfaction with the individual main activity as an indicator of subjective well-being (SWB) or happiness. An appealing quality of the ECHP in the present respect is the setup where the same survey questionnaire is used in $15 \mathrm{EU}$ member countries in a panel running over the eight years from 1994 to 2001. This presents an option for contributing to the literature on the eventual relationship between income and subjective well-being on the individual level, i.e. both the relationship with own income and the eventual importance of relative income where the individual income is benchmarked against the income for a reference group or against own earlier income performance.

We are testing five hypotheses in the paper. The first hypothesis relates directly to the socalled "Easterlin paradox" of a lacking relationship between real income growth and subjective wellbeing. We analyse the eventual impact from income on reported levels of satisfaction for a pooled dataset consisting of the first seven waves of the ECHP. The second hypothesis is that the level of SWB depends on changes in some of the determinants besides depending on the level of other stationary, determinants. The third hypothesis is that the change in individual income relative to the average change in income in the country has an impact on the level of SWB. The fourth hypothesis is that income acceleration has a significant impact on the level of SWB. This is a test using individual data of the robustness of previous results by Bjørnskov et. al. (2008) working with macro data. Finally, the fifth hypothesis is that the change in SWB is determined by the change in a set of health, living and individual labour market conditions in addition to the change in income.

The data in the ECHP makes it possible to test the hypotheses using an estimation approach moving from a specification where the level of satisfaction is regressed against the level of a number of explanatory variables, to a specification still using the level of SWB as the explained variable but introducing changes in a number of the explanatory variables. Finally, the panel property of the data makes it possible to use the change in individual SWB as the explained variable to be regressed against the change in a number of explanatory variables. This strategy makes it possible to 
distinguish between the impact from own income, from relative income and from income acceleration on SWB.

In Section 2 we give a brief survey of part of the recent litterature on happiness in relation to economic and demographic factors with special emphasis on the income-happiness relationship. In Section 3 we describe briefly the ECHP data being used and the specific question we use as the SWB indicator. Section 4 present a number of illustrative examples of the cross-country differences in the average value of SWB and examples of cross-country difference in the distribution over response categories to the relevant question. Section 5 contains the estimation results from a number of probit and multinomial probit analyses where economic, labour market and demographic variables are regressed against the level of individual SWB. Next, Section 5 contains the results from a set of estimations utilizing the panel property of the data by regressing changes in the time varying variables against the change in individual SWB. Finally, Section 6 summarizes and concludes the paper.

\section{Brief survey of the literature}

A central starting point in the literature was Easterlin $(1974,1995)$ concluding that average SWB in the USA had been stationary for decades of increasing real GDP per capita. Blanchflower and Oswald (2004) found the same approximately flat level of average SWB in Great Britain from the early 1970s to the late 1990s. After controlling for a number of individual characteristics Blanchflower and Oswald (2004) however found evidence of a significantly upward movement in well-being over these nearly three decades. The original Easterlin $(1974,1995)$ finding was appropriately termed "the Easterlin paradox". The flat level of average SWB found by Easterlin runs counter to a conventional economic interpretation of SWB as representing utility expected to correlate positively with real GDP per capita ${ }^{1}$.

A principal solution in utility terms of the Easterlin Paradox is presented in the comprehensive paper by Clark et al. (2008). Studies using micro data typically find a positive correlation between SWB and income. A unified explanation of no or little correlation between SWB and income in time series and positive correlation in cross sections using micro data is found by expanding a utility function with a relative income term. This could be income relative to a reference group at

\footnotetext{
${ }^{1}$ A broad introduction to the relevance of happiness research for economics can be found in Frey and Stutzer (2002).
} 
the same point in time or own current income relative to earlier income. If income for a specific individual, for a group, or the average income for a country rises faster than for a relevant reference group, SWB would increase with income as long as this situation persisted. Stated in a different way, adaptation to a higher income lasts longer when you are the first - or among the first - to move up in income. In an analysis using Eurobarometer SWB data for a period of 30 years, Bjørnskov et al. (2008) found evidence that an accelerated growth in real GDP per capita resulted in a significant positive impact on average national SWB. Headey (2006) presents an alternative interpretation of the short run/long run challenge by setting it in the frame of the Set Point theory from psychology and letting the dynamic equilibrium adaptation consist of a gradual shifting of the individual Set Point as a reaction to changes in income.

McBride (2001) working with data from the General Social Survey finds micro level evidence of relative income effects which are found to be less important at low incomes. Mentzakis and Moro (2009) use 8 waves of the British Household Panel to study the impact on SWB from both the level of income and from relative income. They find a positive impact from increases in income, however only up to a certain level. Their results indicate, not just that the impact disappears from a certain level, but that the functional relationship with income is non-linear with a peak in SWB occurring for individuals with incomes below the highest level. The interpretation is - as of the findings in McBride (2001) - that relative income becomes more important in the highest income group.

A very special “natural experiment”, i.e. the German re-unification, offered an oportunity to study the impact from an unexpected strong increase in income for the population in East Germany. Using data from the German Socioeconomic Panel (GSOEP), Frijters et al. (2004) found a clear positive impact on SWB lasting nearly 10 years until adaptation had occurred to the new higher level of income. Ferrer-i-Carbonell (2005) is also using the GSOEP to study the impact on SWB from own income against the impact from relative income. She finds that the income in the reference group is just as important as own income for SWB. Caporale et al. (2007) working with data from the European Social Survey also find a positive impact from income on happiness and life satisfaction and a negative impact from reference income.

DiTella et al. (2008) working with data in a cross-country setting from Eurobarometer, GSOEP and the World Gallup Poll find that the cross-section impact from income becomes flat from a certain 
level, but the adaptation to an increase in income may last longer than 5 years. Ball and Chernova (2008) using data from the World Values Survey find significant impacts on happiness from both absolute and relative income with relative income having the largest effect and with the interesting contribution that the impact from both income measures are small when seen relative to the importance of a number of non-pecuniary factors. Scoppa and Ponzo (2008) confirm this result in a study using Bank of Italy data for 2004 and 2006 finding that several non-economic factors are highly important for SWB. At the same time they find a significant effect from own and relative labour income and a highly significant effect from wealth, real as well as financial wealth. The influence from wealth is also one of the topics in Headey et al. (2008). Using national panels from 5 countries they find a stronger impact on satisfaction from wealth than from income. Further, using the panel property of the data they find that changes in income, consumption and wealth have significant effects on changes in the level of satisfaction.

The ambition in Stevenson and Wolfers (2008) is to evaluate the validity of the original Easterlin puzzle by drawing together several data sets for a number of countries. They find - in contrast to the original puzzle - a clear positive link between average SWB and real GDP per capita in a crosscountry setting and find no evidence of an income saturation point beyond which further increases in income is without effect on SWB. Comparing changes in SWB and in income over time in the individual countries they find a clear positive relationship. Finally, Stevenson and Wolfers (2008) conclude that the effect from absolute income dominates the relative income effect.

Summing up the results regarding the SWB-income relationship in a number of recent studies it seems the original Easterlin Paradox is no longer a puzzle. More datasets covering longer periods and more countries and including more explanatory variables seems without exception to point to a significant positive relationship between SWB and absolute as well as relative income for a reference group. There does not seem to be agreement regarding the relative importance of the two income measures, while several studies agree on the significance of income, but emphasize that non-economic factors appear to be more important than income. The present paper is a contribution in this line of research using the opportunity to test the five hypotheses on a broad panel data set including several countries over a period of years. The next section gives a brief presentation of the data to be used. 


\section{Data and measures of subjective well-being}

The most recent ECHP data were collected in 2001 covering about 60.500 households or 130.000 adults aged 16 year or more. It is based on harmonized questionnaires in the participating countries. The focus in the ECHP is on household income and a broad range of attitudes and living conditions. The data includes items on health, education, housing and demographic and employment characteristics. Data were collected in eight waves from 1994 to 2001. Full ECHP data formats are available for Belgium, Denmark, France, Greece, Ireland, Italy, the Netherlands, Spain and Portugal. For Austria and Finland, data are available for, respectively 1995 - 2001 and 1996 - 2001. For Germany and UK, ECHP data formats are derived from National Surveys for part of the period, the German Socioeconomic Panel and the British Household Panel, respectively. For Luxembourg and Sweden this is also the case for the years $1997-2001$.

The present study is based on a subset of data from the ECHP. In the first part of the estimations we use the first 7 waves of the ECHP to test the validity of the Easterlin paradox. Subsequently we narrow the focus by using data only from two of the most recent waves of the ECHP, i.e. waves 6 and 7, collected in respectively 1999 and 2000 to test the hypotheses involving the change in either some of the explanatory variables or involving as well the change in the level of satisfaction. Our cross-sectional analyses in section 4 below are based on wave 7 .

The ECHP does not contain any direct question concerning happiness or satisfaction with life in general. In the following we use the response to a question regarding satisfaction with ones main activity as indicator for the level of subjective well-being. The variable, called pk001 in the ECHP, is categorical with six different response levels ${ }^{2}$. There are a number of alternative questions in the ECHP on well-being, but these are not relevant for the whole population which is in focus here but only for those in employment at the time of the surveys. Further, we include a number of explanatory background variables in the analysis, all taken from the ECHP. Section 4 contains some brief illustrations of the cross-country variation in the average value of pk001 and the distribution on response categories in four countries selected as representatives for the different European welfare state types, cf. Esping-Andersen (1990).

\footnotetext{
${ }^{2}$ See Bertrand and Mullainathan (2001) for a discussion of the validity of answers to this type of survey questions.
} 


\section{Trend and cross-country differences in measures of well-being}

Only few data sources contain indicators of well-being collected over extended periods of time. The Eurobarometer data is to our knowledge the longest data set collecting measures of well-being in a consistent way for the EU countries. Eurobarometer data have been collected since 1972 for an increasing number of countries along with the entry of new member states to the European Union. The Eurobarometer has, however, not the panel property of the ECHP as it is a sequence of crosssection surveys.

To give an impression of the cross-country range in the well-being indicator, Figure 1 shows the average value of the ECHP variable pk001 for wave 7 collected in 2000. There appears to be a fairly clear North-South divide, with the four Southern European EU countries having the lowest average values of the satisfaction indicators, and the smaller Northern and Continental member states having the highest average values.

Figure 1. Average value the response to question PK001 in wave 7

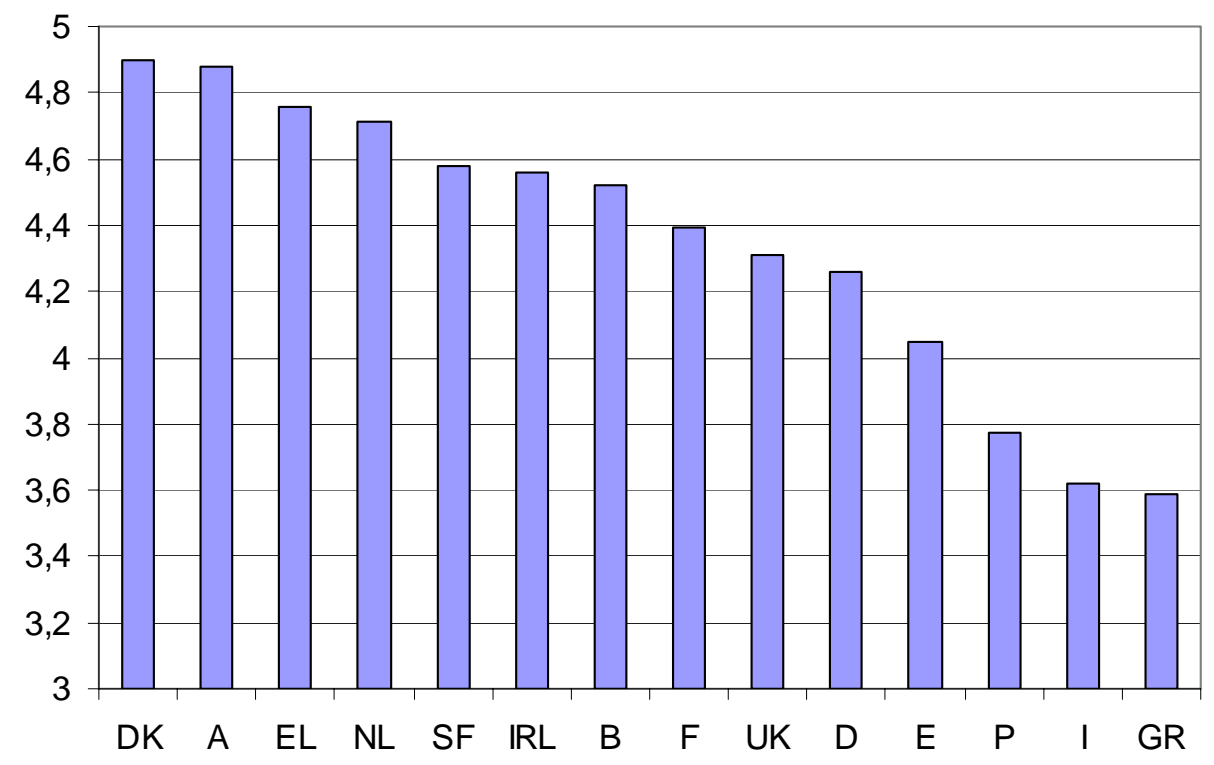

Source: European Household Community panel, wave 7 and own calculations

Note: Denmark (DK), Austria (A), Luxembourg (EL), Netherlands (NL), Finland (SF), Ireland (IRL), Belgium (B), France (F), United-Kingdom (UK), Germany (D), Spain (E), Portugal (P), Italy (I) and Greece (GR) 
In this section we present a few illustrations using data from four countries, Denmark, France, Ireland and Italy, as being representative for each of four different types of European welfare states. Denmark is included as representative for the Nordic or Social democratic model, France as representative for the so-called continental type of welfare state, Ireland represents the liberal welfare state, and Italy, finally, is chosen as representative for the Southern European type of welfare state.

Next in this section Figure 2 shows the distribution on response categories for pk001 in wave 7 in each of these four countries. For Italy, the distribution is nearly symmetrical while especially Denmark and Ireland have most of the density in the top categories ${ }^{3}$.

Figure 2. Distribution on response categories to PK001. Wave 7.

Denmark

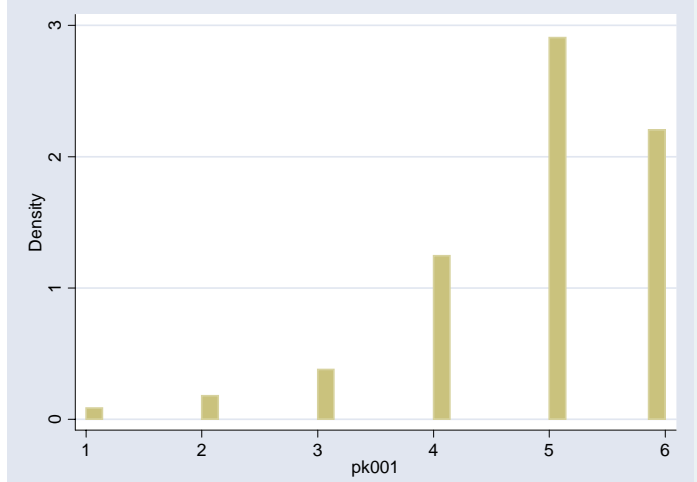

France

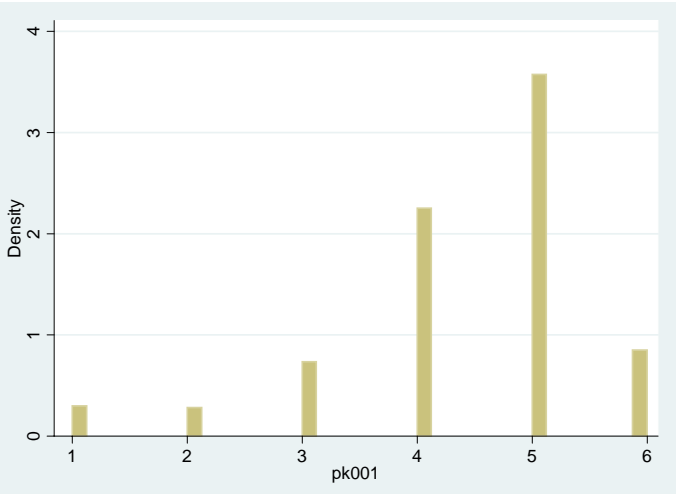

\footnotetext{
${ }^{3}$ For Italy Scoppa and Ponco (2008) show the corresponding distribution and the 0 to 10 scale used in the Bank of Italy data has a mode at the response level 7.
} 

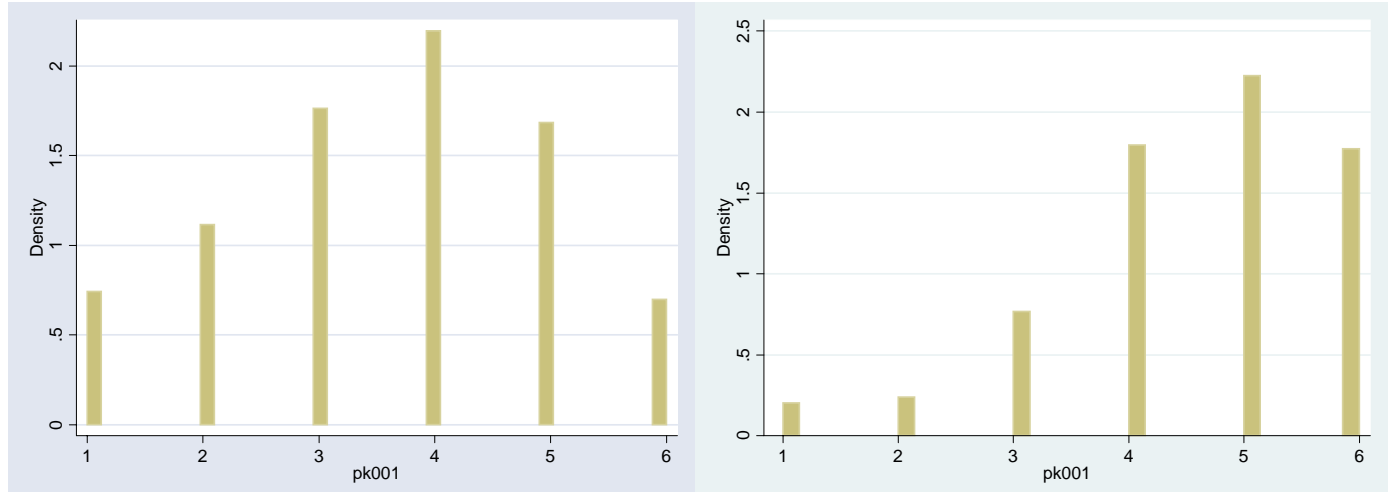

Source: European Community Household Panel, wave 7.

An interesting question is whether the distribution on response categories in pk001 is stable over the 8 waves of the ECHP. An illustration using one country, Denmark, as case, is given in Figure 3 showing the shares for the three top categories of responses to pk001over the 8 waves. The top category 6 is decreasing through the panel, while categories 5 and 4 go up. Overall, however, the total shares in categories $4-6$ is extremely stable falling with 0,2 percentage points from wave 1 to wave 8. 
Figure 3. The relative distribution on top three response categories in PK001. Denmark as case.

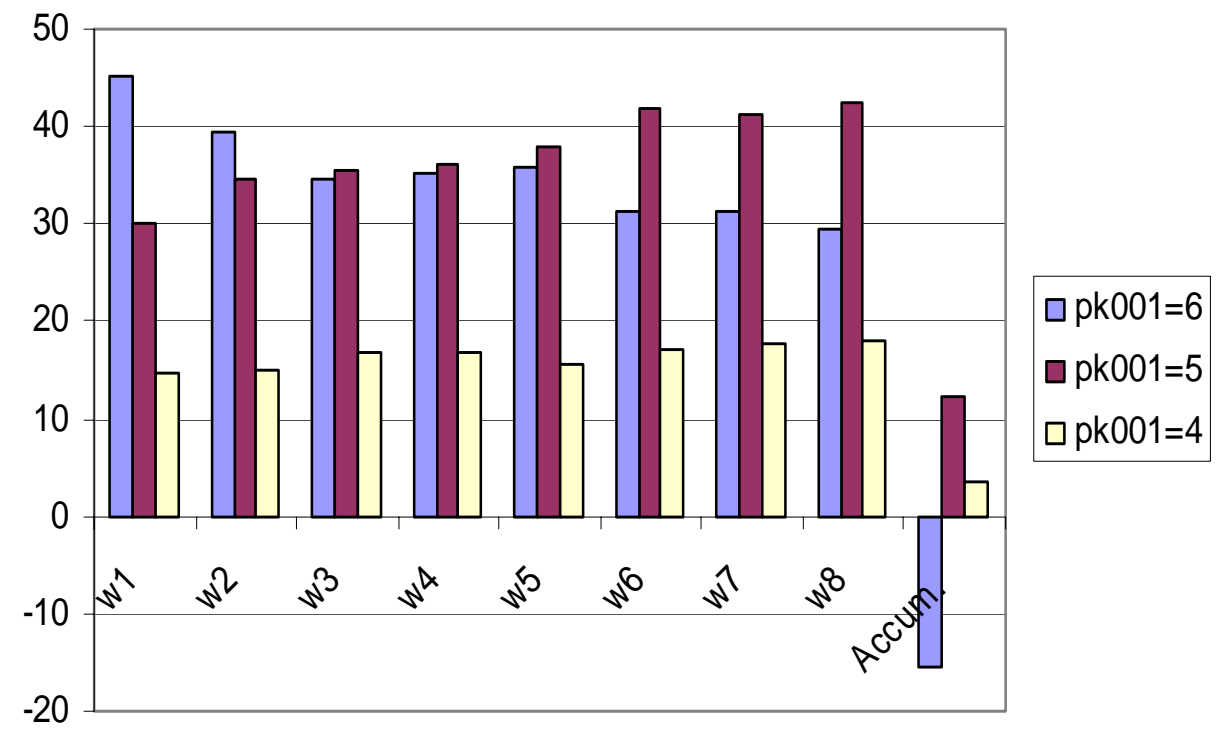

Source: European Community Household Panel, wave 1-8.

\section{Model and estimation results}

In the estimations reported in this Section we use the ECHP variable reporting the level of satisfaction with the individual's main activity as the measure of individual subjective well-being. In Table 1 we present the results from a number of probit analyses where the dependent variable is a dichotomous transformation of the well-being or satisfaction measure, pk001, set at 1 for pk001 $=\{4,5,6\}$ and set at 0 for pk001 $=\{1,2,3\}$. The main hypothesis tested in Table 1 is whether there is an impact from the level of income on the reported level of well-being in a cross section using the ECHP data pooled over the waves 1- 7.

Our income variable, eqiinc, is defined as disposable household income adjusted by the number of members in the household using the OECD equivalence scale. To get a manageable scale for the coefficient estimates we divide the equivalence scale adjusted income with 1.000 .000 before the estimations. The result in Table 1 is the finding of a highly significant impact on our measure of well-being from the level of income measured in this way in all the countries ${ }^{4}$.

\footnotetext{
${ }^{4}$ We have tested the sensitivity of using the equal splitting of the variable pk001 by running the estimations shifting the cutoff point one response level up, respectively down. This did not have any impact on the estimates compared with the equal split variable used in Table 1. Furthermore, Table 1 has been run as an ordered probit analysis on pk001 without changes in the material results in the more simple presentation in Table 1.
} 
We include another income indicator, i.e. the variable incimprove, set at 1 if the household reports, in the answer to hf015, that the present financial situation is either clearly or somewhat better than a year ago and set at 0 if the financial situation is either unchanged or has deteriorated. Here too, we find a positive and significant impact. The partial conclusion tends to be that the higher the income and the more positive the income profile since last year, the higher is the level of subjective wellbeing.

The age of the respondent is introduced in three intervals, the core age group relative to the labour force 25-59 years, people aged 60 and older, and those yonger than 25 as the reference group. A very clear result is found for the 60+ group where the coefficient, i.e. the measure of well-being relative to the young, is significantly positive for all the countries, in Italy however with significance only at the 10 percent level. For the middle aged group, the results regarding wellbeing relative to the young are much less clear. Only few coefficients are significant, and with different signs. Overall, the result does not support the finding in other data sets of an U-shaped profile of well-being over the life cycle, see Blanchflower and Oswald (2007).

Among the other demographic variables a gender dummy, female, set at 1 for women, comes out significantly negative in the southern European countries Spain, Greece, Italy and Portugal. Living in a couple has a significantly positive impact on well-being in all the countries. This is measured by the variable cohab set at 1 for individuals living in a couple, married or cohabiting, and set at 0 otherwise ${ }^{5}$. We have also tried a dummy variable, childunder12, set at 1 if there is one or more children younger than 12 years in the household. There is, however, no reflection of cross country differences in fertility in this variable which with few exceptions is insignificant.

Next, we turn to the variable mainacti which is set at 1 for people who are in the labour force, i.e. working 15 or more hours per week or unemployed, and set at 0 for people who are economically inactive. No clear results are found for this variable in relation to the level of satisfaction or happiness. It is significantly negative in four countries, significantly positive in two and insignificant in the remaining seven countries. Being in the labour force or not seems not to have any systematic impact on satisfaction across countries. We return below to the impact from changes in individual labour market states.

\footnotetext{
${ }^{5}$ This finding is however not sufficient to answer the question set up in the title of Stutzer and Frey (2005), i.e. “Does Marriage make People Happy or do Happy People get Married?”.
} 
Turning to the education indicators, two dummy variables for, respectively secondary and third level of education with primary education as the reference category, we find a significantly higher level of satisfaction for individuals with secondary, and even more with tertiary education, with individuals with primary education as the reference group. This is slightly more pronounced in the group of southern Europen countries. Next, a strong impact on satisfaction is - as expected found from the variable, badhealth, set at 1 if the response to the question ph001 "How is your health in general?” is “fair, bad or very bad” and set at 0 if the answer is “good or very good”.

We have included two neighbourhood indicators which are available in the ECHP, i.e. whether pollution and/or crime is seen as a problem in the area where the respondent lives ${ }^{6}$. With few exceptions a polluted neighbourhood implies a lower level of satisfaction. The effect is even stronger looking to the importance of living in a crime affected neighbourhood which is having a negative impact on satisfaction in all the countries. The last variable included in Table 1 is networkmem set at 1 if the individual responds with yes to question pr002, "Are you a member of any club, such as sport or entertainment club, a local or neighbourhood group, a party etc?”. This measure of an outgoing or extrovert life style has a significant impact on satisfaction in all the countries.

In Table 2 we report the results from testing of two hypotheses. The first one is a test of whether the level of satisfaction is influenced by a number of changes in some of the determinants besides depending on the level of other, more stationary, determinants The dependent variable - as in Table 1 - is the level of well-being set at 1 if pk001 $=\{4,5,6\}$ and set at 0 for pk001=\{1,2,3\}. Instead of the level of individual equivalence scale adjusted income used in Table 1, we use the variable chmeaneqiinc measured as the change in income for the individual between waves 6 and 7 relative to the average change for all individuals between these two waves. The hypothesis is the existence of an impact on individual well-being depending on how own income changes relative to the average change in society at large. In that sense it represents a simple test of the relative income importance or Duesenberrys idea in consumption theory of the importance for own consumption of consumption for a reference group of other individuals. In the present setting, the idea is to test if individual well-being is higher, the stronger individual income increases relative to the average in

\footnotetext{
${ }^{6}$ See Cohen (2008) for a study with focus on the eventual effects from crime on life satisfaction.
} 
society considered as "the reference group". We find significantly positive coefficients to this relative income change in the four southern European countries. Notice this is not a test of the relative income hypothesis strictly comparable to most of the studies discussed in Section 3.

Secondly, we test a simple hypothesis of "acceleration" in the relative change in income variable by including for each individual also the difference between the change in equivalent income from waves 6 and 7, and the corresponding change in equivalent income between waves 5 and 6 . This is the variable chg2meaneqiinc in Table 2. Only for three of the southern European countries is the coefficient significant and negative, i.e. for those three countries a faster change in individual income has a positive impact, but acceleration in average individual income has a moderating effect.

Besides these income variables, we include a number of other change variables. The first one, deltahealth, is defined as the difference between the values of the health variable in waves 7 and 6 . The range in deltahealth is $(-4,4)$ with 4 indicating the highest improvement in reported health between the two waves. The hypothesis underlying the specification is that improvements in health implies a higher level of well-being. This hypothesis is clearly verified with positive coefficients, nearly all significant, for all the countries. Compared with the results in Table 1, we thus have that not only the current level of the health indicator, but also the change, has a significant impact on the current level of well-being. The next variable, deltacohab, is correspondingly defined as the change in the variable cohab between waves 6 and 7, with 1 being the value if a person has entered marriage or cohabitation, -1 is the value in case of divorce or exit from cohabitation and 0 indicates an unchanged situation. It is evident that changes in marital status from one year to the next is without any significant effect on satisfaction.

The next three variables in Table 2 are indicators for changes in labour market status between waves 6 and 7, with eu indicating a change from employment to unemployment, ue indicating the reverse movement and finally with $\ln$ indicating an exit from the labour force to become economically inactive. Turning to these variables, we find for all countries a significantly negative impact on the current level of satisfaction as a consequence of a transition from being in a job to unemployment $^{7}$. This corresponds to the findings in Ahn et al. (2006), also working with ECHP

\footnotetext{
${ }^{7}$ See Winkelmann and Winkelmann (1998) for a study with focus on the impact from unemployment on happiness.
} 
data, of substantial reductions in satisfaction levels from unemployment, however with quite big differences between countries. A change from unemployment in wave 6 to being in a job in wave 7 has no significant impact on the level of current well-being in most of the countries. For Spain and Portugal we find a surprising negative impact. This could be interpreted as an effect on current satisfaction from having experienced unemployment in the past relative to individuals without this experience. Finally, we find that leaving the labour force has a significant negative relationship with the current level of satisfaction in the southern European countries. The interpretation is not straightforward. As the dependent variable measures the satisfaction with the current individual activity one possibility is that this is predominantly voluntary exits from less satisfying work situations. An alternative is however, that the lower level of satisfaction among those who exits from the labour force is a reflection of marginalisation and exclusion processes resulting in nonvoluntary transitions out of the labour force.

Besides these change variables, we include a number of level variables, i.e. age intervals, gender, a dummy for child/children younger than 12 and the two educational dummies which are used also in Table 1 . The only systematic result regarding the age variables is the finding as in Table 1 of mostly significantly higher levels of satisfaction for the older than 60 group relative to young. For the other demographic variables the pattern is about the same as in Table 1. The only exception is the gender variable where more coefficients are negative compared with the results in Table 1.

Table 3 reports the results from estimating a multinomial probit model where the dichotomous level variable for satisfaction which is the dependent variable in Tables 1 and 2 is replaced by a specification of the change in reported well-being between waves 6 and 7. If pk001 changes from pk001 $=\{1,2,3\}$ in wave 6 to pk001=\{4,5,6\} in wave 7 , the change variable is set at 1 indicating a jump up in well-being. The reverse change, from pk001 $=\{4,5,6\}$ to $p k 001=\{1,2,3\}$ is set at -1 , and a stationary level of well-being measured in this way is set at 0 . The coefficients in Table 3 comes from the multinomial probit where a decrease respectively an increase in well-being is set against a stationary level. The interpretation of the signs of coefficients in Table 3 is thus depending on which row we are looking upon. Regarding the rows for -1 , a positive coefficient means that higher values of a specific variable increases the probability of a decline in satisfaction, and vice versa for a negative coefficient. Correspondingly, a positive coefficient to a variable in the +1 rows implies that higher values of this variable increases the probability of a jump up in satisfaction. 
Looking first at the change in income variable we find very few significant effects. Only for four countries do we find that an individual acceleration in income growth significantly reduces the probability of a decrease in satisfaction. Only for one country, Ireland, does an accelerated individual income growth increase the probability of a jump up in satisfaction. The change in the health indicator has much more systematic effects. For Belgium, Finland and Ireland there is no effect, but for all other countries we find that an improved health assessment either reduces the probability of a decline in satisfaction and/or increases the probability of a jump up in satisfaction. We find - as in Table 2 - that changes in marital status is without a significant impact in the yearto-year setting we are using here.

A transition from a job to unemployment significantly increases the probability of a reduction in well-being in all the countries. The reverse transition has a corresponding significant positive impact on the probability of an increase in satisfaction in all the countries. For Italy, it furthermore means a reduction in the probability of a decline in satisfaction, while it is difficult to interpret the results for Belgium and Ireland, i.e. that transition to a job should increase the probability of a decline in satisfaction. Finally, a transition out of the labour force consistently implies a higher probability of an increase in satisfaction. This is in clear contrast to the finding of mostly insignificant coefficients to $\ln$ in estimations on the level of satisfaction reported in Table 2. It is however not inconsistent with the finding in Table 2 of a negative relationship with the level of satisfaction in four of the countries, i.e. those who leave the labour force have - at least in those countries - a lower level of satisfaction in their current activity, but leaving the labour force implies a jump up in satisfaction with their new main activity

\section{Summary and concluding remarks}

The above analyses resulted in a number of fairly clear results regarding factors influencing both the level and the change in subjective well-being. This is the case regarding the impact from the level of income, from the family and health indicators, and from belonging to the older part of the population, which clearly tends to increase satisfaction with the individual main activity. Furthermore, we find some clear and strong effects on subjective well-being from changes in labour market status with negative impact from entering unemployment and positive effects from the reverse transition and from leaving the labour force. 
Regarding determinants of the level of satisfaction or subjective well-being, the main findings can be summarized as:

- A significant positive impact from equivalence scale adjusted income which is in contrast to the socalled Easterlin paradox but in line with findings from a number of recent studies building on quite broad data sets

- A significant positive impact from an assessed improved income situation compared with last year

- Dominance of significantly positive impact from belonging to the $60+$ group

- Significantly lower satisfaction with main activity for women in the Southern European EU countries

- Significantly higher level of satisfaction for married and cohabitating people

- Significantly higher satisfaction for people with higher than primary education, especially among those with third level education

- Significant negative impact from transitions from a job to unemployment

- Positive impact from both level of and change in a self assessed health indicator

Regarding determinants of the change in subjective well-being, the main findings are:

- Improvements in the self assessed health situation has a significantly positive impact on changes in satisfaction in the majority of the countries

- Transitions from a job to unemplyment has a significant impact on the probability of a decline in satisfaction in all the countries

- A transition from unemployment to a job has an equally clear impact on the probability of an increase in satisfaction

- Regarding the effect of an exit from the labour force, the dominant result is a positive impact on the probability of an increase in subjective well-being

Summarizing the results relative to the five hypotheses outlined in the introduction we find regarding the first hypothesis a clear rejection of the Easterlin paradox as current income overall has a significant impact on current SWB. The second hypothesis is confirmed regarding the impact from changes in health and in labour market status. The third hypothesis regarding the change in individual income relative to the average change has an impact only for the Southern European countries. The fourth hypothesis, that acceleration in individual income should have a positive 
impact on the level of SWB is not confirmed. On the contrary, acceleration has a moderating impact on SWB in three of the Southern European countries. Finally, the fifth hypothesis regarding the impact on changes in SWB from changes in explanatory variables is confirmed regarding health and labour market indicators while no impact is found from changes in relative income.

Some policy considerations following from the results in the present paper seem to be:

- Unemployment affects well-being in different degrees in different EU countries reflecting differences in benefit programmes and the risk of long term unemployment, but an ambitious and successful job creation policy will have clear positive effects on satisfaction in all the EU countries included in the present analysis

- Most exits from the labour force appear to be voluntary as they correlate positively with increases in satisfaction.

- Senior citizens classified as the 60+ group are clearly the age group with the highest age related score on the satisfaction with main activity indicator. This, combined with the immediately above mentioned finding is a clear candidate explaining the strong resistance to pension reforms in most European countries. As such reforms in many countries are necessary considering the demographic prospects, it seems that an obvious policy conclusion is that pension reforms increasing the average retirement age, have to include elements like more flexibility, learning new skills and other challenges in senior work life to "compensate” for the clear age/retirement gain in subjective well-being found in the present study to be characteristic of the current setup of early retirement options, pension programmes and labour market structures.

The present paper has focused on determinants of the level of SWB and the processes of change in SWB in different European countries. The findings indicate that in spite of quite different levels of SWB in the countries, the determinants do to a large extent seem to be stable across different welfare state and labour market policy regimes. There are however some indications that the southern European countries are distinct regarding the importance of relative income change for SWB. 


\section{References}

Ahn, N., J.R. Garcia and J.F. Jimeno. 2006. Cross-country Differences in Well-being Consequences of Unemployment in Europe. Working Paper. FEDEA, Bank of Spain. Madrid.

Ball, R. and K. Chernova. 2008. Absolute Income, Relative Income, and Happiness. Social Indicators Research, 88: 497-529.

Bertrand, M. and S. Mullainathan. 2001. Do People Mean What They Say? Implications for Subjective Survey Data. The American Economic Review. Papers and Proceedings: 67-72.

Bjørnskov, C., N. Datta Gupta and P.J. Pedersen. 2008. What Buys Happiness? Analyzing Trends in Subjective WellBeing in 15 European Countries, 1973-2002. Journal of Happiness Studies, 9: 317-330.

Blanchflower, D.G. and A,.J. Oswald.2004. Well-being over time in Britain and the USA. Journal of Public Economics, 88: $1359-1386$.

Blanchflower, D.G. and A. Oswald. 2007. Is Well-Being U-Shaped over the Life Cycle?. NBER WP 12935.

Caporale, G.M., Y. Georgellis, N. Tsitsianis and Y.P. Yin. 2007. Income and Happiness Across Europe: Do Reference Values Matter? CESIFO Working Paper No. 2146.

Clark, A.E., P. Frijters and M.A. Shields. 2008. Relative Income, Happiness, and Utility: An Explanation of the Easterlin Paradox and Other Puzzles. Journal of Economic Literature, Vol. XLVI, Number 1: 95-144.

Cohen, M.A. 2008. The Effect of Crime on Life Satisfaction. Journal of Legal Studies, Vol. 37, june, S325-S353.

Di Tella, R. and R. Macculloch. 2008. Happiness Adaptation to Income Beyond “Basic Needs”. NBER WP 14359.

Easterlin, R.A. 1974. Does Economic Growth Improve the Human Lot? In P.A. David and M.W. Reder (eds.) Nations and Households in Economic Growth: Essays in Honour of Moses Abramowitz. Academic Press. New York.

Easterlin, R.A. 1995. Will Raising the Incomes of All Increase the Happiness of All? Journal of Economic Behavior and Organisation, 27(1): 35-47.

Esping-Andersen, G. (1990). The Three Worlds of Welfare Capitalism. Princeton University Press.

Ferrer-i-Carbonell, A. 2005. Income and Well-Being: An Empirical Analysis of the Comparison Income Effect. Journal of Public Economics, 89(5-6): 997-1019.

Frey, B.S. and A. Stutzer. 2002. What Can Economists Learn from Happiness Research? Journal of Economic Literature, 40(2): 402-35.

Frijters, P., J. P. Haisken-De-New and M.A. Shields. 2004. Money does Matter! Evidence from Increasing Real Income and Life Satisfaction in East Germany Following Reunification. American Economic Review, 94(3): 730 - 740.

Headey, B. 2006. Extending Dynamic Equilibrium Theory to Account for Both Short Run Stability and Long Term Change. DIW DP 607. Berlin.

Headey, B., R. Muffels and M. Wooden. 2008. Money Does not Buy Happiness: Or Does it? A Reassessment Based on the Combined Effects of Wealth, Income and Consumption. Social Indicators Research, Vol. 87, No. 1: 65-82

McBride, M. 2001. Relative-Income Effects on Subjective Well-Being in the Cross-Section. Journal of Economic Behavior and Organisation, 45(3): 251-278.

Mentzakis, E and M. Moro. 2009. The poor, the rich and the happy: Exploring the link between income and subjective well-being. Journal of Socio-economics, vol. 38, 1: 147-158.

Scoppa, V. and M. Ponzo. 2008. An Empirical Study of Happiness in Italy. The B.E. Journal of Economic Analysis \& Policy, Vol. 8: Iss 1 (contributions) 
Stevenson, B. and J. Wolfers. 2008. Economic Growth and Subjective Well-Being: Reasssessing the Easterlin Paradox. IZA DP No. 3654.

Stutzer, A. and B.S. Frey. 2005. Does Marriage Make People Happy, Or Do Happy People Get Married?.IZA Discussion Paper No. 1811.

Winkelmann, L. and R. Winkelmann. 1998. Why Are the Unemployed So Unhappy? Evidence from Panel Data. Economica, 65(257): 1-15. 


\section{Appendix : Variable definitions}

\begin{tabular}{|c|c|}
\hline satspliteq & $\begin{array}{l}\text { satspliteq }=0 \text { if pk001 }=\{1,2,3\} \text { and satspliteq }=1 \text { if pk001 }=\{4,5,6\} \text { and satspliteq }=. \text { if } \\
\text { pk001 }=\{-8,-9\}\end{array}$ \\
\hline deltasatspliteq & 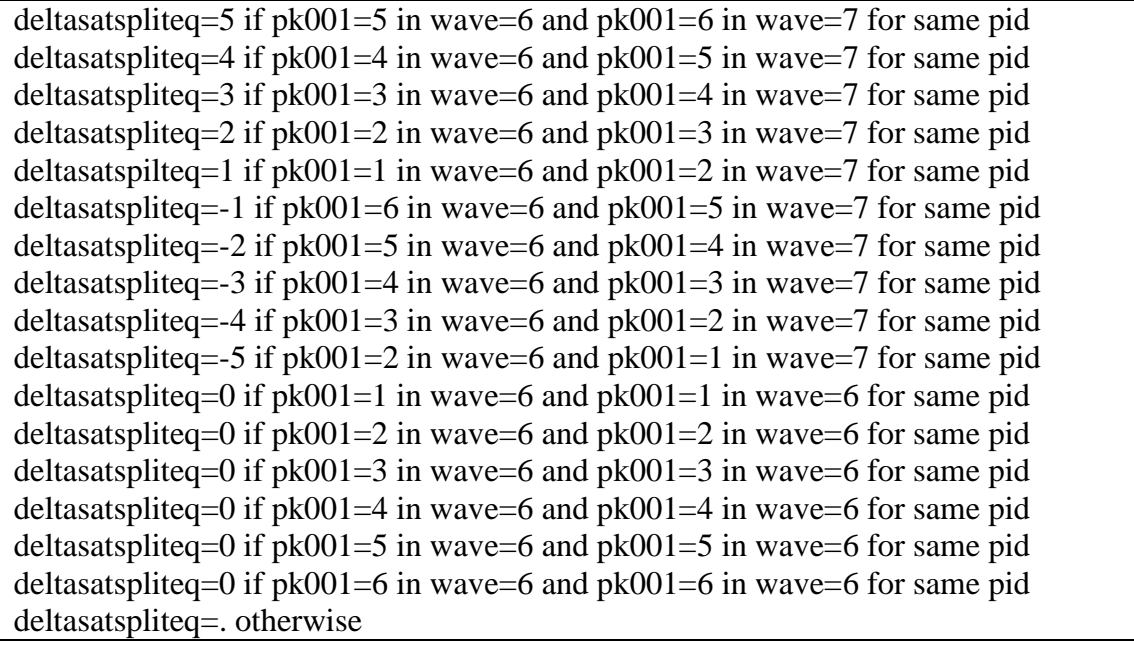 \\
\hline eqiinc & $\begin{array}{l}\text { hi100/(hd004*1000000) where hi100 and hd004 have been corrected such that } \\
\text { hi100 }=\{-8,-9\} \text { or hd004 }=\{-8,-9\} \text { has been set to respectively hi100=. and hd004=. }\end{array}$ \\
\hline incimprove & incimprove $=1$ if hf015 $=\{1,2\}$ and incimprove $=0$ if hf015 $=\{3,4,5\}$ \\
\hline yr25til59 & yr25til59=1 if pd003>=25 \& pd003<=59 and yr25til59=0 otherwise \\
\hline yr60plus & yr60plus $=1$ if pd003 $>59$ and yr60plus $=0$ otherwise \\
\hline lagyr25til59 & lagged value of yr25til60 \\
\hline lagyr60plus & lagged value of yr60plus \\
\hline female & female $=0$ if pd004 $=1$ and female $=1$ if pd004 $=2$ and female $=$. otherwise \\
\hline cohab & Cohab $=0$ if pd008=2 and cohab=1 if pd008=1 and cohab=. otherwise \\
\hline childunder12 & $\begin{array}{l}\text { childunder } 12=0 \text { if } \text { hl001=2 and childunder } 12=1 \text { if hl001=1 and childunder } 12=\text {. } \\
\text { otherwise }\end{array}$ \\
\hline mainacti & $\begin{array}{l}\text { mainacti }=1 \text { if pe } 001=\{1,2,3,4,7\} \text { and mainacti }=0 \text { if pe001=\{5,6,7,9,10,11,12 }\} \text { and } \\
\text { mainacti }=\text {. Otherwise }\end{array}$ \\
\hline secondeduc & $\begin{array}{l}\text { secondeduc }=1 \text { if pt022 }=2 \text { and secondeduc }=0 \text { if pt022 }=\{1,3\} \text { and secondeduc }=\text {. } \\
\text { Otherwise }\end{array}$ \\
\hline thirdeduc & thirdeduc $=1$ if pt022 $=1$ and thirdeduc $=0$ if pt022 $=\{2,3\}$ and thirdeduc $=$. otherwise \\
\hline badhealth & $\begin{array}{l}\text { badhealth }=1 \text { if ph001=\{3,4,5 }\} \text { and badhealth }=0 \text { if ph001=\{1,2 }\} \text { and badhealth }=\text {. } \\
\text { otherwise }\end{array}$ \\
\hline pollution & pollution $=1$ if ha $021=1$ and pollution $=0$ if ha $021=0$ and pollution $=$. Otherwise \\
\hline crime & Crime $=1$ if ha022 $=1$ and crime $=0$ if ha022 $=2$ and ha021 $=$. otherwise \\
\hline networkmem & Networkmem=1 if PR002=yes \\
\hline chgmeaneqiinc & $\begin{array}{l}\text { chgmeaneqiinc }=\text { chgeqiinc-meanchgeqiinc for same pid where } \\
\text { chgeqiinc }=\text { eqiinc in wave }=7 \text { - eqiinc in wave }=6 \text { for same pid and } \\
\text { meanchgeqiinc=mean of chgeqiinc across all pid }\end{array}$ \\
\hline chg2meaneqiinc & $\begin{array}{l}\text { chg2meaneqiinc }=\text { chgmeaneqiinc from wave }=6 \text { to wave }=7-\text { chgmeaneqiinc from } \\
\text { wave }=5 \text { to wave }=6\end{array}$ \\
\hline deltabadhealth & $\begin{array}{l}\text { deltabadhealth }=0 \text { if badhealth }=0 \text { in wave }=6 \text { and badhealth }=0 \text { in wave }=7 \text { for same pid } \\
\text { deltabadhealth }=0 \text { if badhealth }=1 \text { in wave }=6 \text { and badhealth }=1 \text { in wave }=7 \text { for same pid } \\
\text { deltabadhealth }=1 \text { if badhealth }=1 \text { in wave }=6 \text { and badhealth }=0 \text { if wave }=7 \text { for same pid } \\
\text { deltabadhealth }=-1 \text { if badhealth }=0 \text { in wave }=6 \text { and badhelath }=1 \text { in wave }=7 \text { for same pid } \\
\text { deltabadhealth }=\text {. Otherwise }\end{array}$ \\
\hline deltahealth & $\begin{array}{l}\text { deltahealth }=4 \text { if ph001 }=2 \text { in wave }=6 \text { and } p h 001=1 \text { in wave }=7 \text { for same pid } \\
\text { deltahealth }=3 \text { if ph001=3 in wave }=6 \text { and ph001 }=2 \text { in wave }=7 \text { for same pid } \\
\text { deltahealth }=2 \text { if } p h 001=4 \text { in wave }=6 \text { and ph001 }=3 \text { in wave }=7 \text { for same pid } \\
\text { deltahealth }=1 \text { if ph001 }=5 \text { in wave }=6 \text { and ph001 }=4 \text { in wave }=7 \text { for same pid } \\
\text { deltahealth }=-1 \text { if ph001 }=1 \text { in wave }=6 \text { and ph001 }=2 \text { in wave }=7 \text { for same pid }\end{array}$ \\
\hline
\end{tabular}




\begin{tabular}{|c|c|}
\hline & 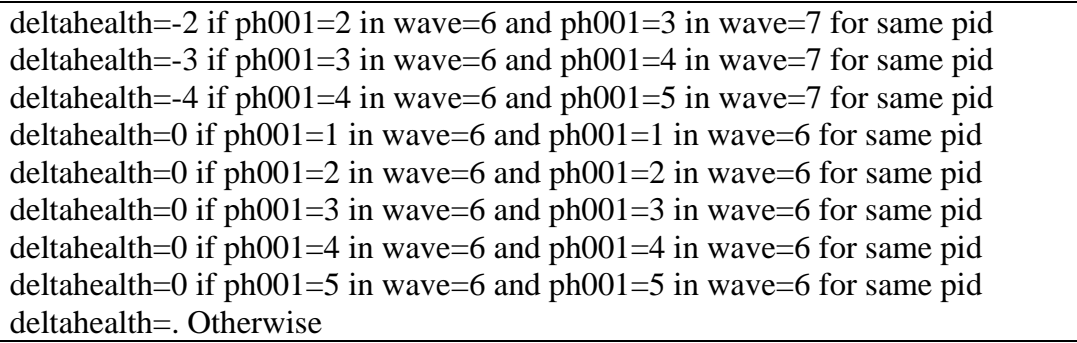 \\
\hline deltacohab & $\begin{array}{l}\text { deltacohab }=0 \text { if pd } 008=1 \text { in wave }=6 \text { and pd } 008=1 \text { in wave }=7 \text { for same pid } \\
\text { deltacohab }=0 \text { if pd } 008=2 \text { in wave }=6 \text { and } p d 008=2 \text { in wave }=7 \text { for same pid } \\
\text { deltacohab }=1 \text { if pd } 008=2 \text { in wave }=6 \text { and pd } 008=1 \text { in wave }=7 \text { for same pid } \\
\text { deltacohab }=-1 \text { if pd } 008=1 \text { in wave }=6 \text { and pd } 008=2 \text { in wave }=7 \text { for same pid } \\
\text { deltacohab }=\text { Otherwise }\end{array}$ \\
\hline ue & $\begin{array}{l}\text { ue }=1 \text { if pe } 001=7 \text { in wave }=6 \text { and pe } 001=1 \text { in wave }=7 \text { for same pid } \\
\text { ue }=1 \text { if pe001 }=7 \text { in wave }=6 \text { and pe } 001=2 \text { in wave }=7 \text { for same pid } \\
\text { ue }=1 \text { if pe001 }=7 \text { in wave }=6 \text { and pe001 }=3 \text { in wave }=7 \text { for same pid } \\
\text { ue }=1 \text { if pe001 }=7 \text { in wave }=6 \text { and pe } 001=4 \text { in wave }=7 \text { for same pid } \\
\text { ue }=. \text { if pe } 001=. \text { in wave }=6 \\
\text { ue }=. \text { if pe } 001=. \text { in wave }=7 \\
\text { ue }=0 \text { otherwise }\end{array}$ \\
\hline eu & $\begin{array}{l}\text { eu }=1 \text { if pe } 001=1 \text { in wave }=6 \text { and pe } 001=7 \text { in wave }=7 \text { for same pid } \\
\text { eu }=1 \text { if pe001=2 in wave }=6 \text { and pe001 }=7 \text { in wave }=7 \text { for same pid } \\
\text { eu }=1 \text { if pe001 }=3 \text { in wave }=6 \text { and pe001 }=7 \text { in wave }=7 \text { for same pid } \\
\text { eu }=1 \text { if pe001 }=4 \text { in wave }=6 \text { and pe001 }=7 \text { in wave }=7 \text { for same pid } \\
\text { eu }=. \text { if pe } 001=. \text { in wave }=6 \\
\text { eu }=. \text { if pe } 001=. \text { in wave }=7 \\
\text { eu }=0 \text { otherwise }\end{array}$ \\
\hline $\ln$ & $\begin{array}{l}\ln =1 \text { if pe } 001=\{1,2,3,4,7\} \text { in wave }=6 \text { and } p e 001=\{5,6,8,9,10,11,12\} \text { for same pid } \\
\ln =. \text { if pe } 001=. \text { in wave }=6 \\
\ln =. \text { if pe } 001=\text {. in wave }=7 \\
\ln =0 \text { otherwise }\end{array}$ \\
\hline
\end{tabular}


Table 1. Probit estimation on the satisfaction variable taking value 0 for pk001=\{1,2,3\} and value 1 for pk001=\{4,5,6 $\}$

\begin{tabular}{|c|c|c|c|c|c|c|c|c|c|c|c|c|c|}
\hline & ustria & elgium & enmark & Spain & Finland & France & Germany & Greece & Ireland & Italy & Netherlands & Portugal & UK \\
\hline eqiinc & $\begin{array}{c}1.721^{\star \star \star} \\
(9.72) \\
0.286^{\star \star \star}\end{array}$ & $\begin{array}{c}0.311^{\star \star \star} \\
(4.19) \\
0.084^{\star \star \star}\end{array}$ & $\begin{array}{c}0.811^{* \star} \\
(3.02) \\
0.130^{* *}\end{array}$ & $\begin{array}{c}0.258^{\star \star \star} \\
(18.96) \\
0.092^{\star \star \star}\end{array}$ & $\begin{array}{c}4.098^{\star \star \star} \\
(10.45) \\
0.917^{\star \star \star}\end{array}$ & $\begin{array}{c}3.083^{\star \star \star} \\
(10.15) \\
0.750^{\star \star \star}\end{array}$ & $\begin{array}{c}10.568^{\star \star \star} \\
(9.90) \\
3.171^{\star \star \star}\end{array}$ & $\begin{array}{c}0.234^{\star \star \star} \\
(25.47) \\
0.093^{\star \star \star}\end{array}$ & $\begin{array}{c}21.126^{\star \star} \\
(2.58) \\
5.423^{\star \star}\end{array}$ & $\begin{array}{c}28.748^{\star \star \star} \\
(29.73) \\
11.279^{\star \star \star}\end{array}$ & $\begin{array}{c}3.754^{\star \star \star} \\
(4.73) \\
0.587^{\star \star \star}\end{array}$ & $\begin{array}{c}0.352^{\star \star \star} \\
(20.06) \\
0.127^{\star \star \star}\end{array}$ & $\begin{array}{c}9.886^{\star \star \star} \\
(4.31) \\
2.770^{\star \star \star}\end{array}$ \\
\hline incimprove & $\begin{array}{c}0.100^{\star \star \star} \\
(3.31) \\
0.016^{\star \star *}\end{array}$ & $\begin{array}{c}0.130^{\star \star \star} \\
(5.24) \\
0.034^{\star \star \star}\end{array}$ & $\begin{array}{c}0.129^{\star \star \star} \\
(4.66) \\
0.020^{\star \star \star}\end{array}$ & $\begin{array}{c}0.190^{\star \star \star} \\
(12.91) \\
0.065^{\star \star *}\end{array}$ & $\begin{array}{c}0.192^{\star \star \star} \\
(8.14) \\
0.041^{* \star *}\end{array}$ & $\begin{array}{c}0.214^{\star \star \star} \\
(10.70) \\
0.048^{\star \star \star}\end{array}$ & $\begin{array}{c}0.179^{\star \star \star} \\
(6.10) \\
0.052^{\star \star \star}\end{array}$ & $\begin{array}{c}0.181^{\star \star \star} \\
(8.10) \\
0.072^{\star \star \star}\end{array}$ & $\begin{array}{c}0.234^{\star \star \star} \\
(10.56) \\
0.058^{\star \star \star}\end{array}$ & $\begin{array}{c}0.148^{\star \star \star} \\
(9.04) \\
0.057^{\star \star *}\end{array}$ & $\begin{array}{c}0.143^{\star \star \star} \\
(7.25) \\
0.022^{\star \star \star}\end{array}$ & $\begin{array}{c}0.168^{\star \star \star} \\
(8.64) \\
0.059^{\star \star \star}\end{array}$ & $\begin{array}{c}0.137^{\star \star \star} \\
(5.92) \\
0.037^{* \star *}\end{array}$ \\
\hline yr25til59 & $\begin{array}{l}0.020 \\
(0.53) \\
0.003\end{array}$ & $\begin{array}{l}-0.029 \\
(-0.63) \\
-0.008\end{array}$ & $\begin{array}{l}0.078 \\
(1.73) \\
0.013\end{array}$ & $\begin{array}{c}-0.067^{\star \star \star} \\
(-3.43) \\
-0.024^{\star \star \star}\end{array}$ & $\begin{array}{l}0.080^{\star} \\
(2.11) \\
0.018^{\star}\end{array}$ & $\begin{array}{c}0.124^{\star \star \star} \\
(4.16) \\
0.031^{\star \star \star}\end{array}$ & $\begin{array}{l}-0.089 \\
(-1.75) \\
-0.026\end{array}$ & $\begin{array}{c}0.081^{\star \star} \\
(3.27) \\
0.032^{\star \star}\end{array}$ & $\begin{array}{l}0.037 \\
(1.02) \\
0.010\end{array}$ & $\begin{array}{l}-0.040 \\
(-1.93) \\
-0.016\end{array}$ & $\begin{array}{c}-0.187^{\star \star \star} \\
(-4.84) \\
-0.028^{\star \star \star}\end{array}$ & $\begin{array}{l}0.010 \\
(0.40) \\
0.004\end{array}$ & $\begin{array}{c}-0.094^{\star \star} \\
(-2.62) \\
-0.026^{\star \star}\end{array}$ \\
\hline female & $\begin{array}{c}0.104^{\star \star \star} \\
(3.96) \\
0.017^{\star \star \star}\end{array}$ & $\begin{array}{l}-0.007 \\
(-0.26) \\
-0.002\end{array}$ & $\begin{array}{l}-0.034 \\
(-1.20) \\
-0.005\end{array}$ & $\begin{array}{c}-0.071^{\star \star \star} \\
(-5.43) \\
-0.025^{\star \star \star}\end{array}$ & $\begin{array}{c}0.103^{\star \star \star} \\
(4.47) \\
0.023^{\star \star \star}\end{array}$ & $\begin{array}{l}-0.025 \\
(-1.32) \\
-0.006\end{array}$ & $\begin{array}{l}0.039 \\
(1.49) \\
0.012\end{array}$ & $\begin{array}{c}-0.095^{\star \star \star} \\
(-6.02) \\
-0.038^{\star \star \star}\end{array}$ & $\begin{array}{c}0.122^{\star \star \star} \\
(4.73) \\
0.031^{\star \star \star}\end{array}$ & $\begin{array}{c}-0.136^{\star \star \star} \\
(-9.69) \\
-0.053^{\star \star \star}\end{array}$ & & $\begin{array}{c}-0.144^{\star \star \star} \\
(-8.32) \\
-0.052^{\star * \star}\end{array}$ & $\begin{array}{c}0.239^{\star \star \star} \\
(10.52) \\
0.067^{\star * \star}\end{array}$ \\
\hline cohab & $\begin{array}{c}0.128^{\star \star \star} \\
(4.60) \\
0.022^{\star \star \star}\end{array}$ & $\begin{array}{c}0.173^{\star \star \star} \\
(5.63) \\
0.048^{\star \star \star}\end{array}$ & $\begin{array}{c}0.164^{\star \star \star} \\
(5.04) \\
0.028^{\star \star \star}\end{array}$ & $\begin{array}{c}0.175^{\star \star \star} \\
(12.28) \\
0.063^{\star \star \star}\end{array}$ & $\begin{array}{c}0.175^{\star \star \star} \\
(6.48) \\
0.041^{\star \star \star}\end{array}$ & $\begin{array}{c}0.179^{\star \star \star} \\
(8.36) \\
0.045^{\star \star \star}\end{array}$ & $\begin{array}{c}0.081^{* \star} \\
(2.63) \\
0.025^{* *}\end{array}$ & $\begin{array}{c}0.148^{\star \star \star} \\
(8.41) \\
0.059^{\star \star \star}\end{array}$ & $\begin{array}{c}0.146^{\star \star \star} \\
(5.30) \\
0.038^{\star \star \star}\end{array}$ & $\begin{array}{c}0.255^{\star \star \star} \\
(16.12) \\
0.100^{\star \star \star}\end{array}$ & $\begin{array}{c}0.249^{\star \star \star} \\
(9.41) \\
0.042^{\star \star \star}\end{array}$ & $\begin{array}{c}0.081^{\star \star \star} \\
(4.33) \\
0.030^{\star \star \star}\end{array}$ & $\begin{array}{c}0.177^{\star \star \star} \\
(6.90) \\
0.051^{\star \star \star}\end{array}$ \\
\hline childunder12 & $\begin{array}{l}-0.028 \\
(-0.99) \\
-0.005\end{array}$ & $\begin{array}{l}-0.017 \\
(-0.58) \\
-0.005\end{array}$ & $\begin{array}{l}-0.049 \\
(-1.51) \\
-0.008\end{array}$ & $\begin{array}{l}0.028 \\
(1.93) \\
0.010\end{array}$ & $\begin{array}{l}0.046 \\
(1.64) \\
0.010\end{array}$ & $\begin{array}{l}0.050^{*} \\
(2.37) \\
0.012^{*}\end{array}$ & $\begin{array}{l}-0.019 \\
(-0.63) \\
-0.006\end{array}$ & $\begin{array}{c}0.085^{\star \star \star} \\
(4.88) \\
0.034^{\star \star \star}\end{array}$ & $\begin{array}{l}-0.024 \\
(-0.83) \\
-0.006\end{array}$ & $\begin{array}{l}0.040^{*} \\
(2.51) \\
0.016^{*}\end{array}$ & & & $\begin{array}{l}0.027 \\
(1.03) \\
0.008\end{array}$ \\
\hline mainacti & $\begin{array}{l}-0.008 \\
(-0.25) \\
-0.001\end{array}$ & $\begin{array}{c}-0.081^{\star} \\
(-2.27) \\
-0.022^{*}\end{array}$ & $\begin{array}{l}0.038 \\
(0.98) \\
0.006\end{array}$ & $\begin{array}{c}-0.200^{\star \star \star} \\
(-13.23) \\
-0.071^{\star \star \star}\end{array}$ & $\begin{array}{c}-0.284^{\star \star \star} \\
(-8.87) \\
-0.060^{\star \star \star}\end{array}$ & $\begin{array}{c}-0.229^{\star \star \star} \\
(-9.48) \\
-0.055^{\star \star \star}\end{array}$ & $\begin{array}{l}-0.011 \\
(-0.34) \\
-0.003\end{array}$ & $\begin{array}{c}-0.074^{\star \star \star} \\
(-4.16) \\
-0.030^{\star \star \star}\end{array}$ & $\begin{array}{l}-0.045 \\
(-1.54) \\
-0.012\end{array}$ & $\begin{array}{l}0.015 \\
(0.96) \\
0.006\end{array}$ & & $\begin{array}{c}0.224^{\star \star \star} \\
(12.05) \\
0.082^{\star \star \star}\end{array}$ & $\begin{array}{c}0.083^{\star *} \\
(2.78) \\
0.024^{\star \star}\end{array}$ \\
\hline secondeduc & $\begin{array}{c}0.112^{\star \star \star} \\
(4.03) \\
0.019^{\star \star \star}\end{array}$ & $\begin{array}{l}0.025 \\
(0.88) \\
0.007\end{array}$ & $\begin{array}{l}0.027 \\
(0.82) \\
0.004\end{array}$ & $\begin{array}{c}0.108^{\star \star \star} \\
(6.27) \\
0.038^{\star \star \star}\end{array}$ & $\begin{array}{l}0.016 \\
(0.59) \\
0.003\end{array}$ & $\begin{array}{l}0.015 \\
(0.78) \\
0.004\end{array}$ & $\begin{array}{l}0.068^{\star} \\
(2.39) \\
0.020^{\star}\end{array}$ & $\begin{array}{c}0.326^{\star \star \star} \\
(17.74) \\
0.129^{\star \star \star}\end{array}$ & $\begin{array}{l}0.050 \\
(1.74) \\
0.013\end{array}$ & $\begin{array}{c}0.219^{\star \star \star} \\
(14.78) \\
0.085^{\star \star \star}\end{array}$ & $\begin{array}{l}0.064^{\star *} \\
(3.19) \\
0.010^{\star \star}\end{array}$ & $\begin{array}{c}0.294^{\star \star \star} \\
(10.55) \\
0.100^{\star \star \star}\end{array}$ & $\begin{array}{l}-0.015 \\
(-0.53) \\
-0.004\end{array}$ \\
\hline thirdeduc & $\begin{array}{l}-0.069 \\
(-1.10) \\
-0.012\end{array}$ & $\begin{array}{c}0.158^{\star \star \star} \\
(4.39) \\
0.042^{\star \star \star}\end{array}$ & $\begin{array}{l}0.060 \\
(1.52) \\
0.010\end{array}$ & $\begin{array}{c}0.124^{\star \star \star} \\
(6.26) \\
0.043^{\star \star *}\end{array}$ & $\begin{array}{l}0.075^{\star} \\
(2.30) \\
0.016^{\star}\end{array}$ & $\begin{array}{c}0.079^{\star \star} \\
(3.03) \\
0.019^{\star \star}\end{array}$ & $\begin{array}{c}0.158^{\star \star \star} \\
(4.07) \\
0.046^{\star \star \star}\end{array}$ & $\begin{array}{c}0.537^{\star \star \star} \\
(21.30) \\
0.208^{\star \star \star}\end{array}$ & $\begin{array}{c}0.172^{\star \star \star} \\
(3.50) \\
0.042^{\star \star \star}\end{array}$ & $\begin{array}{c}0.329^{\star \star \star} \\
(11.30) \\
0.124^{\star \star \star}\end{array}$ & & $\begin{array}{c}0.378^{\star \star \star} \\
(8.21) \\
0.125^{\star * \star}\end{array}$ & $\begin{array}{l}0.028 \\
(1.07) \\
0.008\end{array}$ \\
\hline badhealth & $\begin{array}{c}-0.579^{\star \star \star} \\
(-22.78) \\
-0.113^{\star \star \star}\end{array}$ & $\begin{array}{c}-0.566^{\star \star \star} \\
(-21.36) \\
-0.171^{\star \star \star}\end{array}$ & $\begin{array}{c}-0.604^{\star \star \star} \\
(-20.50) \\
-0.120^{\star \star \star}\end{array}$ & $\begin{array}{c}-0.403^{\star \star \star} \\
(-30.93) \\
-0.147^{\star \star \star}\end{array}$ & $\begin{array}{c}-0.332^{\star \star \star} \\
(-14.05) \\
-0.078^{\star \star \star}\end{array}$ & $\begin{array}{c}-0.479^{\star \star \star} \\
(-29.96) \\
-0.121^{\star \star \star}\end{array}$ & $\begin{array}{c}-0.455^{\star \star \star} \\
(-17.13) \\
-0.144^{\star \star \star}\end{array}$ & $\begin{array}{c}-0.116^{\star \star \star} \\
(-6.47) \\
-0.046^{\star \star \star}\end{array}$ & $\begin{array}{c}-0.505^{\star \star \star} \\
(-19.36) \\
-0.148^{\star \star \star}\end{array}$ & $\begin{array}{c}-0.376^{\star \star \star} \\
(-29.65) \\
-0.148^{\star \star \star}\end{array}$ & $\begin{array}{c}-0.579^{\star \star \star} \\
(-27.75) \\
-0.109^{\star \star \star}\end{array}$ & $\begin{array}{c}-0.252^{\star \star \star} \\
(-15.35) \\
-0.091^{\star \star \star}\end{array}$ & $\begin{array}{c}-0.421^{\star \star \star} \\
(-19.80) \\
-0.125^{\star \star \star}\end{array}$ \\
\hline pollution & $\begin{array}{c}-0.237^{\star \star \star} \\
(-6.17) \\
-0.045^{\star \star \star}\end{array}$ & $\begin{array}{l}-0.015 \\
(-0.46) \\
-0.004\end{array}$ & $\begin{array}{l}-0.096 \\
(-1.91) \\
-0.016\end{array}$ & $\begin{array}{c}-0.053^{\star \star \star} \\
(-3.32) \\
-0.019^{\star \star \star}\end{array}$ & $\begin{array}{c}-0.095^{\star \star} \\
(-3.26) \\
-0.022^{\star \star}\end{array}$ & $\begin{array}{c}-0.110^{\star \star \star} \\
(-5.34) \\
-0.028^{\star \star \star}\end{array}$ & $\begin{array}{c}-0.117^{\star \star \star} \\
(-3.48) \\
-0.036^{\star \star \star}\end{array}$ & $\begin{array}{c}0.180^{\star \star \star} \\
(8.92) \\
0.072^{\star \star \star}\end{array}$ & $\begin{array}{c}-0.151^{\star \star \star} \\
(-3.89) \\
-0.041^{\star \star \star}\end{array}$ & $\begin{array}{c}-0.070^{\star \star \star} \\
(-4.58) \\
-0.028^{\star \star \star}\end{array}$ & $\begin{array}{c}-0.103^{\star \star \star} \\
(-3.85) \\
-0.017^{\star \star \star}\end{array}$ & $\begin{array}{c}-0.129^{\star \star \star} \\
(-5.68) \\
-0.048^{\star \star \star}\end{array}$ & $\begin{array}{c}-0.155^{\star \star \star} \\
(-5.17) \\
-0.046^{\star \star \star}\end{array}$ \\
\hline crime & $\begin{array}{c}-0.244^{\star \star *} \\
(-5.73) \\
-0.047^{\star \star *}\end{array}$ & $\begin{array}{c}-0.126^{\star \star *} \\
(-4.63) \\
-0.035^{\star \star *}\end{array}$ & $\begin{array}{c}-0.170^{\star * *} \\
(-4.65) \\
-0.030^{\star \star \star}\end{array}$ & $\begin{array}{c}-0.116^{\star \star *} \\
(-8.24) \\
-0.042^{\star \star \star}\end{array}$ & $\begin{array}{c}-0.098^{\star * \star} \\
(-3.93) \\
-0.023^{\star \star \star}\end{array}$ & $\begin{array}{c}-0.164^{\star * \star} \\
(-9.16) \\
-0.042^{\star \star \star}\end{array}$ & $\begin{array}{c}-0.161^{\star * *} \\
(-4.29) \\
-0.051^{\star \star \star}\end{array}$ & $\begin{array}{c}-0.063^{*} \\
(-2.39) \\
-0.025^{\star}\end{array}$ & $\begin{array}{c}-0.168^{\star * *} \\
(-5.38) \\
-0.046^{\star \star \star}\end{array}$ & $\begin{array}{c}-0.151^{\star \star *} \\
(-9.47) \\
-0.060^{\star \star \star}\end{array}$ & $\begin{array}{c}-0.150^{\star \star *} \\
(-6.65) \\
-0.025^{\star \star \star}\end{array}$ & $\begin{array}{c}-0.067^{\star *} \\
(-2.85) \\
-0.025^{\star \star}\end{array}$ & $\begin{array}{c}-0.099^{\star * *} \\
(-4.16) \\
-0.028^{\star \star *}\end{array}$ \\
\hline networkmem & $\begin{array}{c}0.243^{\star \star \star} \\
(10.31) \\
0.040^{\star \star \star}\end{array}$ & $\begin{array}{c}0.217^{\star \star \star} \\
(8.77) \\
0.057^{\star \star \star}\end{array}$ & $\begin{array}{c}0.198^{\star \star \star} \\
(7.61) \\
0.033^{\star \star \star}\end{array}$ & $\begin{array}{c}0.150^{\star \star \star} \\
(11.70) \\
0.052^{\star \star *}\end{array}$ & $\begin{array}{c}0.182^{\star \star \star} \\
(8.57) \\
0.041^{\star \star *}\end{array}$ & $\begin{array}{c}0.199^{\star \star \star} \\
(10.50) \\
0.046^{\star \star *}\end{array}$ & $\begin{array}{c}0.200^{\star \star \star \star} \\
(8.21) \\
0.060^{\star \star \star}\end{array}$ & $\begin{array}{c}0.154^{\star \star \star} \\
(6.34) \\
0.061^{\star \star \star}\end{array}$ & $\begin{array}{c}0.190^{\star \star \star} \\
(8.22) \\
0.048^{\star \star \star}\end{array}$ & $\begin{array}{c}0.264^{\star \star \star} \\
(18.14) \\
0.102^{\star \star \star}\end{array}$ & $\begin{array}{c}0.129^{\star \star \star} \\
(6.61) \\
0.020^{\star \star \star}\end{array}$ & $\begin{array}{c}0.085^{\star \star \star} \\
(3.97) \\
0.031^{\star \star \star}\end{array}$ & $\begin{array}{l}0.051^{*} \\
(2.35) \\
0.014^{\star}\end{array}$ \\
\hline
\end{tabular}




\begin{tabular}{|c|c|c|c|c|c|c|c|c|c|c|c|c|c|}
\hline Observations & 37516 & 26566 & 25850 & 80594 & 31783 & 61281 & 16427 & 60160 & 30422 & 90200 & 51448 & 65618 & 22569 \\
\hline
\end{tabular}

Point estimates in first line of each cell of table, standard errors in parentheses in the second line and marginal effects in third line, significance: *** $p<0.01$, ${ }^{* *} \mathrm{p}<0.05$, ${ }^{*} \mathrm{p}<0.1$ 
Table 2. Probit estimation on the satisfaction variable taking value 0 for $P K 001=\{1,2,3\}$ and value 1 for pk001=\{4,5,6 $\}$ income and labour market status in changes

\begin{tabular}{|c|c|c|c|c|c|c|c|c|c|c|c|}
\hline & Austria & Belgium & Denmark & Spain & Finland & France & Greece & Ireland & Italy & Netherlands & Portugal \\
\hline Chgmeaneqiinc & $\begin{array}{l}-0.280 \\
(-0.43) \\
-0.042\end{array}$ & $\begin{array}{l}0.046 \\
(0.51) \\
0.011\end{array}$ & $\begin{array}{l}-0.603 \\
(-0.47) \\
-0.091\end{array}$ & $\begin{array}{l}0.101^{\star} \\
(2.35) \\
0.035^{\star}\end{array}$ & $\begin{array}{l}2.917 \\
(1.72) \\
0.618\end{array}$ & $\begin{array}{l}1.500 \\
(1.60) \\
0.347\end{array}$ & $\begin{array}{c}0.148^{\star \star \star} \\
(5.52) \\
0.059^{\star \star \star}\end{array}$ & $\begin{array}{c}13.610 \\
(1.12) \\
3.286\end{array}$ & $\begin{array}{c}10.315^{\star \star} \\
(3.21) \\
4.062^{\star \star}\end{array}$ & $\begin{array}{l}-2.054 \\
(-0.63) \\
-0.324\end{array}$ & $\begin{array}{c}0.199^{\star \star} \\
(2.91) \\
0.068^{\star \star}\end{array}$ \\
\hline Chg2meaneqiinc & $\begin{array}{l}0.210 \\
(0.56) \\
0.031\end{array}$ & $\begin{array}{l}0.073 \\
(1.13) \\
0.018\end{array}$ & $\begin{array}{l}0.626 \\
(0.78) \\
0.095\end{array}$ & $\begin{array}{l}-0.048 \\
(-1.64) \\
-0.017\end{array}$ & $\begin{array}{l}-0.726 \\
(-0.74) \\
-0.154\end{array}$ & $\begin{array}{l}-0.694 \\
(-1.36) \\
-0.161\end{array}$ & $\begin{array}{c}-0.078^{\star \star \star} \\
(-5.08) \\
-0.031^{\star \star \star}\end{array}$ & $\begin{array}{c}-10.306 \\
(-1.31) \\
-2.488\end{array}$ & $\begin{array}{l}-4.367^{\star} \\
(-2.28) \\
-1.719^{\star}\end{array}$ & $\begin{array}{l}0.077 \\
(0.05) \\
0.012\end{array}$ & $\begin{array}{c}-0.101^{*} \\
(-2.39) \\
-0.035^{\star}\end{array}$ \\
\hline Deltahealth & $\begin{array}{c}0.060^{\star \star \star} \\
(3.60) \\
0.009^{\star \star \star}\end{array}$ & $\begin{array}{l}0.026 \\
(1.63) \\
0.006\end{array}$ & $\begin{array}{c}0.100^{\star \star \star} \\
(4.67) \\
0.015^{\star \star \star}\end{array}$ & $\begin{array}{c}0.045^{\star \star \star} \\
(5.87) \\
0.016^{\star \star \star}\end{array}$ & $\begin{array}{l}0.025 \\
(1.53) \\
0.005\end{array}$ & $\begin{array}{c}0.048^{\star \star \star} \\
(4.40) \\
0.011^{\star \star \star}\end{array}$ & $\begin{array}{l}0.028^{*} \\
(2.43) \\
0.011^{*}\end{array}$ & $\begin{array}{l}0.024 \\
(1.44) \\
0.006\end{array}$ & $\begin{array}{c}0.032^{\star \star \star} \\
(4.38) \\
0.013^{\star \star \star}\end{array}$ & $\begin{array}{c}0.084^{\star \star \star} \\
(5.50) \\
0.013^{\star \star \star}\end{array}$ & $\begin{array}{c}0.041^{\star \star \star} \\
(4.07) \\
0.014^{\star \star \star}\end{array}$ \\
\hline Deltacohab & $\begin{array}{l}0.044 \\
(0.30) \\
0.007\end{array}$ & $\begin{array}{l}0.122 \\
(0.80) \\
0.030\end{array}$ & $\begin{array}{l}-0.148 \\
(-0.98) \\
-0.022\end{array}$ & $\begin{array}{l}0.050 \\
(0.52) \\
0.017\end{array}$ & $\begin{array}{l}0.214 \\
(1.21) \\
0.045\end{array}$ & $\begin{array}{l}0.158 \\
(1.46) \\
0.037\end{array}$ & $\begin{array}{l}-0.017 \\
(-0.12) \\
-0.007\end{array}$ & $\begin{array}{l}0.135 \\
(0.62) \\
0.032\end{array}$ & $\begin{array}{l}0.013 \\
(0.16) \\
0.005\end{array}$ & $\begin{array}{l}0.187 \\
(1.33) \\
0.029\end{array}$ & $\begin{array}{l}-0.140 \\
(-1.82) \\
-0.048\end{array}$ \\
\hline EU & $\begin{array}{c}-1.448^{\star \star \star} \\
(-8.26) \\
-0.433^{\star \star \star}\end{array}$ & $\begin{array}{c}-1.872^{\star \star \star} \\
(-6.06) \\
-0.650^{\star \star \star}\end{array}$ & $\begin{array}{c}-0.480^{\star} \\
(-2.39) \\
-0.098^{\star}\end{array}$ & $\begin{array}{c}-1.224^{\star \star \star} \\
(-11.91) \\
-0.459^{\star \star \star}\end{array}$ & $\begin{array}{c}-1.038^{\star \star \star} \\
(-7.10) \\
-0.331^{\star \star \star}\end{array}$ & $\begin{array}{c}-1.374^{\star \star \star} \\
(-10.11) \\
-0.479^{\star \star \star}\end{array}$ & $\begin{array}{c}-1.059^{\star \star \star} \\
(-6.37) \\
-0.373^{\star \star \star}\end{array}$ & $\begin{array}{c}-1.616^{\star \star \star} \\
(-6.17) \\
-0.571^{\star \star \star}\end{array}$ & $\begin{array}{c}-1.060^{\star \star \star} \\
(-7.50) \\
-0.381^{\star \star \star}\end{array}$ & $\begin{array}{c}-0.545^{\star} \\
(-2.45) \\
-0.120^{\star}\end{array}$ & $\begin{array}{c}-1.956^{\star \star \star} \\
(-11.20) \\
-0.631^{\star \star \star}\end{array}$ \\
\hline UE & $\begin{array}{l}-0.233 \\
(-0.81) \\
-0.041\end{array}$ & $\begin{array}{l}-0.069 \\
(-0.32) \\
-0.018\end{array}$ & $\begin{array}{l}-0.045 \\
(-0.18) \\
-0.007\end{array}$ & $\begin{array}{c}-0.286^{\star \star \star} \\
(-3.51) \\
-0.106^{\star \star \star}\end{array}$ & $\begin{array}{l}-0.181 \\
(-1.13) \\
-0.042\end{array}$ & $\begin{array}{l}0.280 \\
(1.67) \\
0.056\end{array}$ & $\begin{array}{c}-0.291^{\star} \\
(-2.20) \\
-0.116^{*}\end{array}$ & $\begin{array}{c}-0.485^{\star} \\
(-2.41) \\
-0.144^{\star}\end{array}$ & $\begin{array}{l}-0.110 \\
(-1.26) \\
-0.043\end{array}$ & $\begin{array}{l}0.345 \\
(1.28) \\
0.043\end{array}$ & $\begin{array}{c}-0.442^{\star \star \star} \\
(-3.67) \\
-0.166^{\star \star \star}\end{array}$ \\
\hline $\mathrm{LN}$ & $\begin{array}{l}-0.077 \\
(-0.49) \\
-0.012\end{array}$ & $\begin{array}{l}-0.261 \\
(-1.71) \\
-0.073\end{array}$ & $\begin{array}{l}-0.195 \\
(-1.24) \\
-0.033\end{array}$ & $\begin{array}{c}-0.336^{\star \star \star} \\
(-4.94) \\
-0.125^{\star \star \star}\end{array}$ & $\begin{array}{l}0.153 \\
(1.09) \\
0.030\end{array}$ & $\begin{array}{l}0.141 \\
(1.32) \\
0.030\end{array}$ & $\begin{array}{l}-0.235^{\star} \\
(-2.40) \\
-0.093^{*}\end{array}$ & $\begin{array}{l}0.121 \\
(0.85) \\
0.027\end{array}$ & $\begin{array}{c}-0.381^{\star \star \star} \\
(-5.57) \\
-0.151^{\star \star \star}\end{array}$ & $\begin{array}{l}-0.073 \\
(-0.69) \\
-0.012\end{array}$ & $\begin{array}{c}-0.416^{\star \star \star} \\
(-5.52) \\
-0.155^{\star \star \star}\end{array}$ \\
\hline Lagyr25til59 & $\begin{array}{c}-0.238^{\star \star} \\
(-2.60) \\
-0.034^{\star \star}\end{array}$ & $\begin{array}{c}-0.234^{\star \star} \\
(-2.58) \\
-0.056^{\star \star}\end{array}$ & $\begin{array}{l}0.189 \\
(1.72) \\
0.030\end{array}$ & $\begin{array}{l}-0.005 \\
(-0.11) \\
-0.002\end{array}$ & $\begin{array}{l}0.052 \\
(0.65) \\
0.011\end{array}$ & $\begin{array}{l}0.108 \\
(1.73) \\
0.025\end{array}$ & $\begin{array}{c}0.265^{\star \star \star} \\
(4.91) \\
0.105^{\star \star \star}\end{array}$ & $\begin{array}{l}0.069 \\
(0.85) \\
0.017\end{array}$ & $\begin{array}{c}0.151^{\star \star \star} \\
(4.06) \\
0.060^{\star \star \star}\end{array}$ & $\begin{array}{l}-0.038 \\
(-0.42) \\
-0.006\end{array}$ & $\begin{array}{l}0.040 \\
(0.90) \\
0.014\end{array}$ \\
\hline Lagyr60plus & $\begin{array}{l}-0.044 \\
(-0.46) \\
-0.007\end{array}$ & $\begin{array}{l}0.250^{*} \\
(2.37) \\
0.058^{*}\end{array}$ & $\begin{array}{c}0.414^{\star \star} \\
(3.23) \\
0.053^{\star \star}\end{array}$ & $\begin{array}{c}0.206^{\star \star \star} \\
(4.22) \\
0.070^{\star \star \star}\end{array}$ & $\begin{array}{c}0.392^{\star \star \star} \\
(3.87) \\
0.073^{\star \star \star}\end{array}$ & $\begin{array}{c}0.377^{\star \star \star} \\
(5.32) \\
0.080^{\star \star \star}\end{array}$ & $\begin{array}{c}0.390^{\star \star \star} \\
(6.48) \\
0.153^{\star \star \star}\end{array}$ & $\begin{array}{c}0.260^{\star *} \\
(2.68) \\
0.059^{\star *}\end{array}$ & $\begin{array}{l}0.084 \\
(1.93) \\
0.033\end{array}$ & $\begin{array}{l}0.074 \\
(0.76) \\
0.011\end{array}$ & $\begin{array}{c}-0.232^{\star \star \star} \\
(-4.76) \\
-0.082^{\star \star \star}\end{array}$ \\
\hline Female & $\begin{array}{l}0.000 \\
(0.00) \\
0.000\end{array}$ & $\begin{array}{l}-0.076 \\
(-1.53) \\
-0.019\end{array}$ & $\begin{array}{l}-0.116 \\
(-1.77) \\
-0.017\end{array}$ & $\begin{array}{c}-0.180^{\star \star \star} \\
(-6.68) \\
-0.062^{\star \star \star}\end{array}$ & $\begin{array}{l}0.079 \\
(1.57) \\
0.017\end{array}$ & $\begin{array}{l}-0.053 \\
(-1.55) \\
-0.012\end{array}$ & $\begin{array}{c}-0.094^{\star *} \\
(-3.12) \\
-0.037^{\star *}\end{array}$ & $\begin{array}{l}0.050 \\
(0.93) \\
0.012\end{array}$ & $\begin{array}{c}-0.210^{\star \star \star} \\
(-9.12) \\
-0.083^{\star \star \star}\end{array}$ & $\begin{array}{c}-0.117^{\star \star} \\
(-2.62) \\
-0.018^{\star \star}\end{array}$ & $\begin{array}{c}-0.287^{\star \star \star} \\
(-10.22) \\
-0.098^{\star \star \star}\end{array}$ \\
\hline Childunder12 & $\begin{array}{l}-0.095 \\
(-1.54) \\
-0.015\end{array}$ & $\begin{array}{l}0.019 \\
(0.34) \\
0.005\end{array}$ & $\begin{array}{l}0.031 \\
(0.40) \\
0.005\end{array}$ & $\begin{array}{l}0.036 \\
(1.07) \\
0.012\end{array}$ & $\begin{array}{l}0.016 \\
(0.26) \\
0.003\end{array}$ & $\begin{array}{l}0.047 \\
(1.17) \\
0.011\end{array}$ & $\begin{array}{l}0.016 \\
(0.43) \\
0.006\end{array}$ & $\begin{array}{l}0.017 \\
(0.28) \\
0.004\end{array}$ & $\begin{array}{l}0.051 \\
(1.79) \\
0.020\end{array}$ & $\begin{array}{l}0.042 \\
(0.78) \\
0.007\end{array}$ & $\begin{array}{l}0.055 \\
(1.57) \\
0.019\end{array}$ \\
\hline Secondeduc & $\begin{array}{c}0.349^{\star \star \star} \\
(5.82) \\
0.055^{\star \star \star}\end{array}$ & $\begin{array}{l}0.087 \\
(1.43) \\
0.021\end{array}$ & $\begin{array}{c}0.264^{\star \star} \\
(3.22) \\
0.040^{\star \star}\end{array}$ & $\begin{array}{c}0.275^{\star \star \star} \\
(6.92) \\
0.091^{\star \star \star}\end{array}$ & $\begin{array}{l}0.048 \\
(0.71) \\
0.010\end{array}$ & $\begin{array}{c}0.150^{\star *} \\
(2.62) \\
0.033^{\star *}\end{array}$ & $\begin{array}{c}0.515^{\star \star \star} \\
(13.63) \\
0.199^{\star \star \star}\end{array}$ & $\begin{array}{l}0.088 \\
(1.41) \\
0.021\end{array}$ & $\begin{array}{c}0.403^{\star \star \star} \\
(15.03) \\
0.156^{\star \star \star}\end{array}$ & $\begin{array}{l}- \\
- \\
-\end{array}$ & $\begin{array}{c}0.433^{\star \star \star} \\
(8.65) \\
0.134^{\star \star *}\end{array}$ \\
\hline Thirdeduc & $\begin{array}{c}0.354^{\star \star} \\
(2.79) \\
0.042^{\star \star}\end{array}$ & $\begin{array}{c}0.411^{\star \star \star} \\
(6.28) \\
0.095^{\star \star \star}\end{array}$ & $\begin{array}{l}0.235^{\star} \\
(2.49) \\
0.033^{*}\end{array}$ & $\begin{array}{c}0.379^{\star \star \star} \\
(10.14) \\
0.123^{\star \star \star}\end{array}$ & $\begin{array}{l}0.146^{\star} \\
(1.99) \\
0.030^{\star}\end{array}$ & $\begin{array}{c}0.248^{\star \star \star} \\
(5.65) \\
0.054^{\star \star *}\end{array}$ & $\begin{array}{c}1.102^{\star \star \star} \\
(20.13) \\
0.371^{\star \star \star}\end{array}$ & $\begin{array}{c}0.252^{\star *} \\
(3.07) \\
0.056^{\star *}\end{array}$ & $\begin{array}{c}0.656^{\star \star \star} \\
(14.18) \\
0.235^{\star \star \star}\end{array}$ & $\begin{array}{l}0.150 \\
(0.42) \\
0.021\end{array}$ & $\begin{array}{c}0.928^{\star \star \star} \\
(12.30) \\
0.236^{\star \star \star}\end{array}$ \\
\hline
\end{tabular}


Note: Standard errors in parentheses, ${ }^{* * *} \mathrm{p}<0.01,{ }^{* *} \mathrm{p}<0.05,{ }^{*} \mathrm{p}<0.1$. Germany and Luxembourg have no information on PK001 for wave 7 . All estimations are based on data for wave 7. Estimations are probit estimations for a dichotomous variable defined through an equal split of the scale in PK001 ( 0 if pk001=\{1,2,3\} and 1 if pk001=\{4,5,6\}) 
Table 3. Multinomial probit on the change in the satisfaction variable

\begin{tabular}{|c|c|c|c|c|c|c|c|c|c|c|c|c|}
\hline & $\begin{array}{c}\text { Chg- } \\
\text { sat- } \\
\text { spliteq }\end{array}$ & $\begin{array}{l}\text { Au- } \\
\text { stria }\end{array}$ & $\begin{array}{l}\text { Bel- } \\
\text { gium }\end{array}$ & $\begin{array}{l}\text { Den- } \\
\text { mark }\end{array}$ & Spain & $\begin{array}{l}\text { Fin- } \\
\text { land }\end{array}$ & France & Greece & Ireland & Italy & $\begin{array}{l}\text { Nether- } \\
\text { lands }\end{array}$ & $\begin{array}{c}\text { Portu- } \\
\text { gal }\end{array}$ \\
\hline \multirow[t]{2}{*}{$\begin{array}{l}\text { chgmean- } \\
\text { equiinc }\end{array}$} & -1 & $\begin{array}{l}-0.19 \\
(0.42)\end{array}$ & $\begin{array}{l}-0.09 \\
(0.12)\end{array}$ & $\begin{array}{l}0.12 \\
(1.0)\end{array}$ & $\begin{array}{l}-0.04 \\
(0.03)\end{array}$ & $\begin{array}{l}-3.5^{* *} \\
(1.45)\end{array}$ & $\begin{array}{l}-0.80^{*} \\
(0.45)\end{array}$ & $\begin{array}{l}-0.02 \\
(0.03)\end{array}$ & $\begin{array}{l}-1.72 \\
(6.99)\end{array}$ & $\begin{array}{c}-9.43^{* * *} \\
(2.87)\end{array}$ & $\begin{array}{c}4.16 \\
(2.69)\end{array}$ & $\begin{array}{l}-0.005 \\
(0.05)\end{array}$ \\
\hline & 1 & $\begin{array}{l}-0.05 \\
(0.43)\end{array}$ & $\begin{array}{l}-0.06 \\
(0.10)\end{array}$ & $\begin{array}{c}0.13 \\
(0.99)\end{array}$ & $\begin{array}{l}0.0008 \\
(0.03)\end{array}$ & $\begin{array}{l}-0.84 \\
(1.45)\end{array}$ & $\begin{array}{l}-0.04 \\
(0.59)\end{array}$ & $\begin{array}{c}0.03 \\
(0.02)\end{array}$ & $\begin{array}{c}7.05 \\
(9.25)\end{array}$ & $\begin{array}{c}1.09 \\
(2.93)\end{array}$ & $\begin{array}{c}3.57 \\
(2.63)\end{array}$ & $\begin{array}{l}-0.02 \\
(0.06)\end{array}$ \\
\hline \multirow[t]{2}{*}{ deltahealth } & -1 & $\begin{array}{l}-0.05^{*} \\
(0.03)\end{array}$ & $\begin{array}{l}-0.04 \\
(0.03)\end{array}$ & $\begin{array}{c}-0.10^{\star \star \star} \\
(0.03)\end{array}$ & $\begin{array}{c}-0.05^{* * * *} \\
(0.011)\end{array}$ & $\begin{array}{l}-0.02 \\
(0.03)\end{array}$ & $\begin{array}{c}-0.06^{* * * *} \\
(0.02)\end{array}$ & $\begin{array}{l}-0.001 \\
(0.02)\end{array}$ & $\begin{array}{l}0.005 \\
(0.03)\end{array}$ & $\begin{array}{l}-0.02 \\
(0.01)\end{array}$ & $\begin{array}{c}-0.12 * * * \\
(0.02)\end{array}$ & $\begin{array}{c}-0.05^{* * *} \\
(0.02)\end{array}$ \\
\hline & 1 & $\begin{array}{l}0.05^{* *} \\
(0.02)\end{array}$ & $\begin{array}{l}-0.003 \\
(0.02)\end{array}$ & $\begin{array}{l}0.05^{\star \star} \\
(0.03)\end{array}$ & $\begin{array}{l}0.03^{* *} \\
(0.011)\end{array}$ & $\begin{array}{l}-0.003 \\
(0.03)\end{array}$ & $\begin{array}{l}0.04^{* *} \\
(0.02)\end{array}$ & $\begin{array}{l}0.04^{* *} \\
(0.02)\end{array}$ & $\begin{array}{c}0.02 \\
(0.03)\end{array}$ & $\begin{array}{l}0.03 * * \\
(0.01)\end{array}$ & $\begin{array}{l}-0.02 \\
(0.02)\end{array}$ & $\begin{array}{c}0.02 \\
(0.02)\end{array}$ \\
\hline \multirow[t]{2}{*}{ deltacohab } & -1 & $\begin{array}{c}0.11 \\
(0.21)\end{array}$ & $\begin{array}{l}-0.13 \\
(0.23)\end{array}$ & $\begin{array}{c}0.24 \\
(0.22)\end{array}$ & $\begin{array}{l}-0.11 \\
(0.13)\end{array}$ & $\begin{array}{c}0.05 \\
(0.27)\end{array}$ & $\begin{array}{c}0.06 \\
(0.17)\end{array}$ & $\begin{array}{l}-0.35 \\
(0.26)\end{array}$ & $\begin{array}{l}-0.47 \\
(0.34)\end{array}$ & $\begin{array}{l}-0.004 \\
(0.13)\end{array}$ & $\begin{array}{l}-0.15 \\
(0.17)\end{array}$ & $\begin{array}{c}0.14 \\
(0.13)\end{array}$ \\
\hline & 1 & $\begin{array}{c}0.19 \\
(0.22)\end{array}$ & $\begin{array}{l}0.53^{* *} \\
(0.22)\end{array}$ & $\begin{array}{l}-0.08 \\
(0.21)\end{array}$ & $\begin{array}{c}0.09 \\
(0.14)\end{array}$ & $\begin{array}{c}0.23 \\
(0.26)\end{array}$ & $\begin{array}{c}0.27 \\
(0.16)\end{array}$ & $\begin{array}{l}-0.11 \\
(0.21)\end{array}$ & $\begin{array}{l}-0.50 \\
(0.33)\end{array}$ & $\begin{array}{c}0.12 \\
(0.13)\end{array}$ & $\begin{array}{c}0.15 \\
(0.16)\end{array}$ & $\begin{array}{c}0.08 \\
(0.13)\end{array}$ \\
\hline \multirow[t]{2}{*}{$\mathrm{eu}$} & -1 & $\begin{array}{c}1.95^{* * *} \\
(0.23)\end{array}$ & $\begin{array}{c}1.39 * * * \\
(0.35)\end{array}$ & $\begin{array}{c}0.84^{\star \star \star} \\
(0.28)\end{array}$ & $\begin{array}{c}1.14^{* * * *} \\
(0.13)\end{array}$ & $\begin{array}{c}1.72^{* * *} \\
(0.20)\end{array}$ & $\begin{array}{c}1.84^{* * *} \\
(0.18)\end{array}$ & $\begin{array}{c}0.61^{* * *} \\
(0.20)\end{array}$ & $\begin{array}{c}1.73^{* * *} \\
(0.35)\end{array}$ & $\begin{array}{c}0.90^{* * *} \\
(0.17)\end{array}$ & $\begin{array}{c}1.07^{* * * *} \\
(0.28)\end{array}$ & $\begin{array}{c}1.72^{* * * *} \\
(0.18)\end{array}$ \\
\hline & 1 & $\begin{array}{c}0.44 \\
(0.37)\end{array}$ & $\begin{array}{l}-0.18 \\
(0.60)\end{array}$ & $\begin{array}{l}0.60^{\star} \\
(0.31)\end{array}$ & $\begin{array}{l}-0.07 \\
(0.18)\end{array}$ & $\begin{array}{c}0.39 \\
(0.30)\end{array}$ & $\begin{array}{c}0.43 \\
(0.27)\end{array}$ & $\begin{array}{l}-0.38 \\
(0.26)\end{array}$ & $\begin{array}{c}0.03 \\
(0.60)\end{array}$ & $\begin{array}{l}-0.01 \\
(0.24)\end{array}$ & $\begin{array}{c}0.52 \\
(0.35)\end{array}$ & $\begin{array}{l}-0.18 \\
(0.33)\end{array}$ \\
\hline \multirow[t]{2}{*}{ ue } & -1 & $\begin{array}{c}-23.20 \\
(0)\end{array}$ & $\begin{array}{c}1.34^{* * *} \\
(0.33)\end{array}$ & $\begin{array}{c}0.11 \\
(0.43)\end{array}$ & $\begin{array}{l}-0.06 \\
(0.14)\end{array}$ & $\begin{array}{c}0.28 \\
(0.31)\end{array}$ & $\begin{array}{c}0.23 \\
(0.38)\end{array}$ & $\begin{array}{l}-0.27 \\
(0.28)\end{array}$ & $\begin{array}{c}0.94 * * * \\
(0.34)\end{array}$ & $\begin{array}{c}-0.57^{* *} \\
(0.23)\end{array}$ & $\begin{array}{c}0.34 \\
(0.32)\end{array}$ & $\begin{array}{l}-0.24 \\
(0.32)\end{array}$ \\
\hline & 1 & $\begin{array}{c}1.82 * * * \\
(0.28)\end{array}$ & $\begin{array}{c}2.19 * * * \\
(0.28)\end{array}$ & $\begin{array}{c}1.47^{\star \star \star} \\
(0.27)\end{array}$ & $\begin{array}{c}1.16^{* * *} \\
(0.10)\end{array}$ & $\begin{array}{c}2.02 * * * \\
(0.19)\end{array}$ & $\begin{array}{l}2.8^{* * *} \\
(0.18)\end{array}$ & $\begin{array}{c}0.84^{* * *} \\
(0.17)\end{array}$ & $\begin{array}{c}1.76^{* * *} \\
(0.28)\end{array}$ & $\begin{array}{c}1.42 * * * \\
(0.12)\end{array}$ & $\begin{array}{c}1.55^{* * *} \\
(0.21)\end{array}$ & $\begin{array}{c}1.68^{* * *} \\
(0.16)\end{array}$ \\
\hline \multirow[t]{2}{*}{$\ln$} & -1 & $\begin{array}{c}0.16 \\
(0.23)\end{array}$ & $\begin{array}{c}0.18 \\
(0.26)\end{array}$ & $\begin{array}{c}0.07 \\
(0.25)\end{array}$ & $\begin{array}{c}0.32^{* * *} \\
(0.10)\end{array}$ & $\begin{array}{l}0.31^{*} \\
(0.18)\end{array}$ & $\begin{array}{c}0.11 \\
(0.17)\end{array}$ & $\begin{array}{l}-0.01 \\
(0.17)\end{array}$ & $\begin{array}{c}0.08 \\
(0.22)\end{array}$ & $\begin{array}{c}0.08 \\
(0.11)\end{array}$ & $\begin{array}{c}0.01 \\
(0.16)\end{array}$ & $\begin{array}{c}0.85^{* * * *} \\
(0.11)\end{array}$ \\
\hline & 1 & $\begin{array}{c}0.62^{* * *} \\
(0.19)\end{array}$ & $\begin{array}{l}0.49 * * \\
(0.23)\end{array}$ & $\begin{array}{c}0.78^{\star \star \star} \\
(0.19)\end{array}$ & $\begin{array}{c}0.49^{* * *} \\
(0.10)\end{array}$ & $\begin{array}{c}0.82^{* * *} \\
(0.15)\end{array}$ & $\begin{array}{c}0.85^{* * *} \\
(0.13)\end{array}$ & $\begin{array}{l}0.28^{*} \\
(0.14)\end{array}$ & $\begin{array}{c}0.46^{* *} \\
(0.19)\end{array}$ & $\begin{array}{c}0.29 * * * \\
(0.11)\end{array}$ & $\begin{array}{l}0.32 * * \\
(0.14)\end{array}$ & $\begin{array}{c}0.48^{* * *} \\
(0.12)\end{array}$ \\
\hline \multirow[t]{2}{*}{ constant } & -1 & $\begin{array}{c}-2.22^{* * *} \\
(0.041)\end{array}$ & $\begin{array}{c}-1.79 * * * \\
(0.041)\end{array}$ & $\begin{array}{c}-2.13^{\star \star \star} \\
(0.05)\end{array}$ & $\begin{array}{c}-1.17^{* * *} \\
(0.02)\end{array}$ & $\begin{array}{c}-1.92^{* * *} \\
(0.04)\end{array}$ & $\begin{array}{c}-1.93^{* * *} \\
(0.03)\end{array}$ & $\begin{array}{c}-1.59 * * * \\
(0.027)\end{array}$ & $\begin{array}{c}-1.79 * * * \\
(0.05)\end{array}$ & $\begin{array}{c}-1.45^{* * *} \\
(0.02)\end{array}$ & $\begin{array}{c}-2.09 * * * \\
(0.03)\end{array}$ & $\begin{array}{c}-1.78^{* * *} \\
(0.025)\end{array}$ \\
\hline & 1 & $\begin{array}{c}-2.22^{* * *} \\
(0.041)\end{array}$ & $\begin{array}{c}-1.73^{* * *} \\
(0.040)\end{array}$ & $\begin{array}{c}-2.18^{\star \star \star} \\
(0.05)\end{array}$ & $\begin{array}{c}-1.24^{* * *} \\
(0.022)\end{array}$ & $\begin{array}{c}-1.99 * * * \\
(0.04)\end{array}$ & $\begin{array}{c}-1.95^{* * *} \\
(0.03)\end{array}$ & $\begin{array}{c}-1.32 * * * \\
(0.024)\end{array}$ & $\begin{array}{c}-1.78^{* * *} \\
(0.045)\end{array}$ & $\begin{array}{c}-1.60^{* * *} \\
(0.02)\end{array}$ & $\begin{array}{c}-2.16 * * * \\
(0.03)\end{array}$ & $\begin{array}{c}-1.71^{* * *} \\
(0.024)\end{array}$ \\
\hline $\begin{array}{l}\text { Observa- } \\
\text { tions }\end{array}$ & - & 5293 & 3926 & 3467 & 10918 & 4519 & 8716 & 8290 & 3250 & 13171 & 7745 & 10186 \\
\hline
\end{tabular}

Note: Estimations concern the changes the changes taking place from wave 6 to wave 7 . Standard errors in parentheses, ${ }^{* * *} \mathrm{p}<0.01,{ }^{* *} \mathrm{p}<0.05,{ }^{*} \mathrm{p}<0.1$. Germany and Luxembourg are left out, as the ECHP for wave 7 is based on SOEP and PSELL respectively. These national surveys do not contain information on the variable PK001. 